\title{
pompalina
}

(8)

\section{Encheiridion de Epicteto}

Autor(es): $\quad$ Epicteto; Dinucci, Aldo, trad., autor da introd., coment.; Julien, Alfredo, trad., autor da introd., coment.

Publicado por: Imprensa da Universidade de Coimbra; Annablume editora

URL

persistente: URI:http://hdl.handle.net/10316.2/32825

DOI: $\quad$ DOI:http://dx.doi.org/10.14195/978-989-26-0825-9

Accessed : $\quad$ 26-Apr-2023 16:05:33

A navegação consulta e descarregamento dos títulos inseridos nas Bibliotecas Digitais UC Digitalis, UC Pombalina e UC Impactum, pressupõem a aceitação plena e sem reservas dos Termos e Condições de Uso destas Bibliotecas Digitais, disponíveis em https://digitalis.uc.pt/pt-pt/termos.

Conforme exposto nos referidos Termos e Condições de Uso, o descarregamento de títulos de acesso restrito requer uma licença válida de autorização devendo o utilizador aceder ao(s) documento(s) a partir de um endereço de IP da instituição detentora da supramencionada licença.

Ao utilizador é apenas permitido o descarregamento para uso pessoal, pelo que o emprego do(s) título(s) descarregado(s) para outro fim, designadamente comercial, carece de autorização do respetivo autor ou editor da obra.

Na medida em que todas as obras da UC Digitalis se encontram protegidas pelo Código do Direito de Autor e Direitos Conexos e demais legislação aplicável, toda a cópia, parcial ou total, deste documento, nos casos em que é legalmente admitida, deverá conter ou fazer-se acompanhar por este aviso.

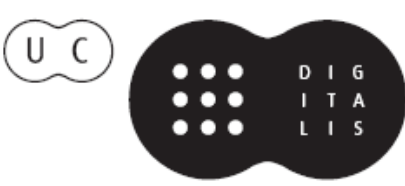




\section{EPICTETO}

\section{ENCHEIRIDION DE EPICTETO}

TRADUÇÃO DO GREGO, INTRODUÇÃO E COMENTÁRIO Aldo Dinucci \& Alfredo Julien 
SÉrie "Autores Gregos e Latinos -

TRADUÇÁ̃o, INTRODUÇẤO E COMENTÁRIO”

ISSN: 2183-220X

Apresentação: Esta série procura apresentar em língua portuguesa obras de autores gregos, latinos e neolatinos, em tradução feita diretamente a partir da língua original. Além da traduçáo, todos os volumes sẫo também caraterizados por conterem estudos introdutórios, bibliografia crítica e notas. Reforça-se, assim, a originalidade científica e o alcance da série, cumprindo o duplo objetivo de tornar acessíveis textos clássicos, medievais e renascentistas a leitores que não dominam as línguas antigas em que foram escritos. Também do ponto de vista da reflexão académica, a coleção se reveste no panorama lusófono de particular importância, pois proporciona contributos originais numa área de investigação científica fundamental no universo geral do conhecimento e divulgação do património literário da Humanidade.

Periodicidade: trimestral

\section{Estruturas Editoriais}

Coordenadores Gerais (General Editors)

A. Centro de Estudos Clássicos e Humanísticos (Coimbra)

- Delfim Leão (Universidade de Coimbra)

- José Ribeiro Ferreira (Universidade de Coimbra)

- Luísa Portocarrero (Universidade de Coimbra)

- Maria do Céu Fialho (Universidade de Coimbra)

- Sebastiāo Pinho (Universidade de Coimbra)

B. Annablume (São Paulo)

- Gabriele Cornelli (Universidade de Brasília)

- Jacyntho Lins Brandāo (Universidade Federal de Minas Gerais)

- Pedro Paulo Funari (Universidade Estadual de Campinas)

Diretor Principal (Main Editor)

- Carmen Leal Soares (Universidade de Coimbra)

- Maria de Fátima Silva (Universidade de Coimbra)

Assistentes editoriais (Editorial Assistants)

- Elisabete Caçáo

- João Pedro Gomes

- Nelson Ferreira

Comissáo Científica (Editorial Board)

- Adriane Duarte (Universidade de São Paulo)

- Aurelio Pérez Jiménez (Universidad de Málaga)

- Graciela Zeccin (Universidade de La Plata)

- Fernanda Brasete (Universidade de Aveiro)

- Fernando Brandão dos Santos (UNESP, Campus de Araraquara)

- Francesc Casadesús Bordoy (Universitat de les Illes Balears)

- Frederico Lourenço (Universidade de Coimbra)

- Joaquim Pinheiro (Universidade da Madeira)

- Lucía Rodríguez-Noriega Guillen (Universidade de Oviedo)

- Jorge Deserto (Universidade do Porto)

- Maria José García Soler (Universidade do País Basco)

- Susana Marques Pereira (Universidade de Coimbra) 


\section{EPICTETO}

ENCHEIRIDION DE EPICTETO

TRADUÇÃO DO GREGO, INTRODUÇÃO E COMENTÁRIO Aldo Dinucci \& Alfredo Julien Universidade Federal de Sergipe

IMPRENSA DA UNIVERSIDADE DE COIMBRA COIMBRA UNIVERSITY PRESS 
Obra ReAlizada no ÂMbito das actividades da UI\&D

Centro de Estudos Clássicos e Humanísticos

\section{Título • Encheiridion de Epicteto}

\section{Autor • Epicteto}

Traduçấo do grego, introduçấo e comentário • Aldo Dinucci \& Alfredo Julien

Série Autores Gregos e Latinos • Tradução, introdução e comentário

\section{Coedição}

Imprensa da Universidade de Coimbra

URL: http://www.uc.pt/imprensa_uc

E-mail: imprensa@uc.pt

Vendas online:

http://livrariadaimprensa.uc.pt

Annablume editora $\cdot$ comunicaçấo

www.annablume.com.br

\section{CoORdENAÇÃo EDITORIAL}

Imprensa da Universidade de Coimbra

Concepção gráfica e Paginação

Rodolfo Lopes, Nelson Ferreira

INFOGRAFIA

Imprensa da Universidade de Coimbra

\author{
Impressão e ACABamento \\ WWW.ARTIPOL.NET
}

ISSN

2183-220X

ISBN

978-989-26-0824-2

\section{ISBN DigitAL}

978-989-26-0825-9

\section{DOI}

http://dx.doi.org/10.14195/

978-989-26-0825-9

Depósito Legal

376709/14

I a EdiçÃo: IUC • 2014

(C) Abril 2014.

Annablume editora - Sáo Paulo

IMPRENSA DA UNIVERSIDADE DE CoIMBRA

Classica Digitalia Vniversitatis Conimbrigensis (http://classicadigitalia.uc.pt) Centro de Estudos Clássicos e Humanísticos da Universidade de Coimbra

\section{FCT \\ Fundação para a Ciência e a Tecnologia}

\section{POCI/2010}

Reservados todos os direitos. Nos termos legais fica expressamente proibida a reprodução total ou parcial por qualquer meio, em papel ou em edição electrónica, sem autorizaçâo expressa dos titulares dos direitos. É desde já excepcionada a utilização em circuitos académicos fechados para apoio a leccionaçấo ou extensāo cultural por via de e-learning.

TODOS OS VOLUMES DESTA SÉRIE SÃO SUJEITOS A ARBITRAGEM CIENTÍFICA INDEPENDENTE. 


\section{SUMÁRIO}

INTRODUÇÃo

Nota biográfica sobre Epicteto, Epafrodito e Musônio 9

A quem se destina e para que serve o Encheiridion de Epicteto 20

Recepção e transmissão do Encheiridion de Epicteto: da era bizantina aos nossos dias $\quad 23$

Sobre a divisão em capítulos do Encheiridion de Epicteto 27

O estabelecimento do texto grego 27

$\begin{array}{ll}\text { ENCHEIRIDION } & 33\end{array}$

$\begin{array}{ll}\text { Bibliografia } & 69\end{array}$

$\begin{array}{ll}\text { INDEX LOCORVM } & 83\end{array}$

$\begin{array}{ll}\text { INDEX RERVM } & 91\end{array}$ 
(Página deixada propositadamente em branco) 
A GIUSEPPE DINUCCI, IN MEMORIAM. A HENRIQUE MURACHCO, MESTRE E AMIGO. 
(Página deixada propositadamente em branco) 


\section{INTRODUÇÃO}

Nota biográfica sobre Epicteto, Epafrodito E Musônio

As informaçôes sobre vida de Epicteto nos vêm de três fontes principais: Aulo Gélio ${ }^{1}$, Simplício ${ }^{2}$ e Suidas ${ }^{3}$. Diz-nos a Suda:

De Hierápolis, [uma cidade] da Frígia; [1] um filósofo; um escravo [2] de Epafrodito, um dos guarda-costas do imperador Nero. [3] Estropiado em uma perna em razáo de reumatismo, [4] viveu em Nicópolis, [5] [uma cidade] da [província de] Épiro [...] [6] sua vida se estendeu até o reinado de Marco Antonino. [7] Escreveu muitos livros ${ }^{4}$.

${ }^{1}$ AULO GÉLIO, Noites Áticas 2.18 e 15.11. Aulo Gélio, autor e gramático latino, viveu entre 125 e 180.

2 Simplício da Cilícia, filósofo neoplatônico bizantino, viveu entre 490 e 560.

3 Suidas foi um lexicógrafo grego do século X. Compôs a Suda, a primeira enciclopédia de que se tem notícia.

${ }^{4}$ Suda, episilon 2424. 
Epicteto confirma ter sido escravo em Diatribes I.9.29 e I.19.21. Uma inscrição em sua homenagem ${ }^{5}$ descoberta em Pisídia ${ }^{6}$, da autoria de certo Leontianus, bem como epigramas citados por João Crisóstomo ${ }^{7}$ Macróbio $^{8}$ e Simplício 9 confirmam ter sido Epicteto um escravo. Sua alcunha, segundo alguns, era comumente dada a escravos e significa "Adquirido"10. Colardeau" sugere, porém, que seu nome designava uma parte da Frígia que fora naqueles tempos anexada ao Império Romano, tendo sido conferido ao futuro filósofo para designar sua terra natal.

Epicteto teria chegado a Roma como servo de Epafrodito, secretário (encarregado de receber petiçóes) de $\mathrm{Nero}^{12}$, segundo Suetônio ${ }^{13}$; chefe dos guarda-costas de Nero, segundo Suidas. Epafrodito, a quem Epicteto referese negativamente algumas vezes nas Diatribes ${ }^{14}$, ajudou Nero a suicidar-se quando este foi proclamado inimigo de Roma pelo Senado em 68, pelo que mais tarde foi condenado à

5 SCHENKL, 1916, p. vii, testemunho XIX.

6 Região da Ásia Menor que foi, por muitos séculos, província do Império Romano. Atual Antalya (Turquia).

7 JOÃO CRISÓSTOMO, Hom. 13 in Acta. IN: Patrologia Graeca 60.111.30. São João Crisóstomo nasceu em Antioquia (atual Antakya), na Síria, aproximadamente em 347, e morreu em 14 de Setembro de 407. Foi teólogo, escritor e arcebispo de Constantinopla do fim do século IV ao início do século $\mathrm{V}$.

8 MACRÓBIO, Saturnálias 1.11.45. Macróbio Ambrósio Teodósio foi escritor e filósofo romano. Compôs as Saturnálias e o Comentário ao Sonho de Cipião. Africano, teria nascido por volta de 370, na Numídia.

${ }^{9}$ SIMPLÍCIO, Commentarius in Epicteti Enchiridion, 45.35; 55.3.

${ }^{10}$ Cf. MARTHA, C., 1865, p. 196.

${ }^{11}$ COLARDEAU, 1903, p. 6, nota 5.

${ }^{12}$ Nero Cláudio César Augusto Germânico nasceu em 15 de dezembro de 37 e faleceu em 9 de junho de 68. Governou Roma entre 54 e 68 e foi o último imperador da dinastia Júlio-claudiana.

13 Cf. SUETÔNIO, Nero. 49.5; Domiciano 14.2. O escritor e historiador romano Caio Suetônio Tranquilo viveu entre 69 e 141.

${ }^{14}$ Cf. Diatribes I.1.20; I.19.19; I.26.11. 
morte por Domiciano ${ }^{15}$. A divergência quanto à função de Epafrodito na corte de Nero pode ser explicada por ter sido de fato secretário no princípio de sua carreira, sendo posteriormente, como prêmio por ter auxiliado Nero no episódio da conspiração de Pisão ${ }^{16}$, encarregado da segurança pessoal do imperador, o que explicaria tê-lo acompanhado nos seus momentos finais, auxiliando-o a suicidar-se. Além disso, alguns historiadores creem ser ele o mesmo Epafrodito a quem Flávio Josefo ${ }^{17}$ dedica seus escritos ${ }^{18}$.

Epicteto se refere ao fato de ser manco em Diatribes I.8.14 e I.16.20. Fontes antigas afirmam que seu defeito físico seria devido à crueldade de Epafrodito ${ }^{19}$. Epicteto é também dito manco (cholos) ou com fraqueza física (soma asthenes) por Simplício $^{20}$. Outros dizem ainda que Epicteto fora mutilado pela violência que teria sofrido de um "tirano na Macedônia"21. Porém, tais testemunhos podem simplesmente supor como

15 Tito Flávio Domiciano nasceu em 24 de outubro de 51 e morreu em 18 de setembro de 96 . Foi imperador de Roma de 14 de setembro de 81 d.C. até a sua morte. Era filho de Tito Flávio Sabino Vespasiano e irmão de Tito Flávio, a quem sucedeu.

16 Caio Calpúrnio Pisão, senador romano que viveu no século I, foi o principal idealizador da Conspiração de Pisão contra Nero. Em 19 de abril de 65 o liberto Mílico traiu Pisão, denunciando-o ao imperador. Dezenove conspiradores foram condenados à morte e outros treze foram exilados. Pisão recebeu e cumpriu a ordem de cometer suicídio.

17 Tito Flávio Josefo (em hebraico 'Yosef ben Matityahura') viveu entre 37 ou 38 e 100 e foi um historiador judaico-romano.

18 Flávio Josefo, em suas obras Antiguidades dos Judeus, Autobiografia e Contra os Gregos, agradece ao seu patrono Epafrodito. Entretanto, não se sabe ao certo se esse é o mesmo senhor de Epicteto (Cláudio Tibério Epafrodito) ou se é Epafrodito de Queroneia (gramático e liberto de Modesto, praefectum do Egito nos anos 50).

19 Cf. GREGÓRIO NAZIANZENO, Oratio I contra Iulianum. IN: Patrologia Graeca 35.592.14; Ep. 32 ad Philagrium 10.2; ORÍGENES. Contra Celsum. IN: Patrologia Graeca 3.368.

20 SIMPLÍCIO, Commentarius in Epicteti enchiridion, 45.36

21 Cf. NONNUS. IN: Patrologia Graeca 36.933; COSMAS DE JERUSALEM. IN: Patrologia Graeca 38.532. 
fato o que é dito pelo próprio Epicteto em Diatribes I.19.8 ${ }^{22}$, razão pela qual Schenk ${ }^{23}$ dá mais crédito à versão de Suidas, pois vê um caráter apotegmático naqueles relatos de maus tratos, pelos quais se opóe a liberdade interior à escravidáo do corpo, tema recorrente em Epicteto.

Não é possível determinar precisamente as datas de nascimento e morte de Epicteto. A partir de Diatribes IV.5.17, podemos inferir que estava vivo sob Trajano ${ }^{24}$. Em Diatribes III.7, Epicteto conversa com um corrector $^{25}$ que alguns historiadores supóem ser o mesmo Máximo mencionado por Plínio em uma carta ${ }^{26}$. Como essa carta é de 108, estima-se que Epicteto morreu após tal data. Suidas, como vimos acima, afirma que Epicteto estaria vivo sob Marco Aurélio ${ }^{27}$, o que não é o caso, pois Epicteto deveria ter 20 anos quando de sua expulsão de Roma por Domiciano em $95^{28}$ e não poderia

22 Onde Epicteto dialoga com um tirano imaginário, argumentando, diante da ameaça de encarceramento e decapitaçáo, que o poder dos tiranos equivale, no máximo, ao poder de matar da febre.

${ }^{23}$ SCHENKL, 1916, p. xv- xxxiii.

${ }^{24}$ Marco Úlpio Nerva Trajano viveu entre 18 de setembro de 53 e 9 de agosto de 117. Foi imperador romano entre 98 e 117, período no qual o Império Romano atingiu sua maior extensão territorial. Seu governo foi marcado por programas de obras públicas e de políticas sociais. $\mathrm{Na}$ passagem mencionada, Epicteto se refere nominalmente a Trajano.

25 Tal cargo surgiu durante o governo de Trajano e era ocupado por oficiais da classe senatorial designados para investigar e corrigir a administração nas províncias.

${ }^{26}$ PLÍNIO O JOVEM, Carta 22. Caio Plínio Cecílio Segundo viveu entre 61 (ou 62) e 114. Foi orador, jurista e político, além de governador imperial na Bitínia entre 111 e 112. Adotado por Plínio o Velho, de quem era sobrinho-neto, foi testemunha ocular da erupção do Vesúvio de 79, sobre o que escreveu.

${ }^{27}$ César Marco Aurélio Antonino Augusto, ou simplesmente Marco Aurélio, viveu entre 26 de abril de 121 e 17 de março de 180 . Foi imperador de Roma entre 161 e 180. Após sua morte foram publicadas suas reflexões filosóficas, que lhe valeram o título de filósofo estoico e seguidor de Epicteto.

${ }_{28}$ Quando Domiciano decretou a expulsão de todos os filósofos e astrólogos de Roma. Epicteto é único filósofo que sabemos nominalmente 
ser, tão novo, um filósofo renomado. Talvez o autor da Suda se ampare em Marco Aurélio 1.7 e 19, passagem na qual o imperador fala com admiração de Epicteto, o que poderia levar o leitor desavisado a crer que Marco o tivesse conhecido. Temístio ${ }^{29}$, por sua vez, afirma que Epicteto estava vivo sob os Antoninos, ou seja, sob Marco Aurélio ou Antonino Pio ${ }^{30}$, que chegou ao poder em $138^{31}$, o que também não é factível. O mais provável é Epicteto ter morrido na altura da metade do reinado de Adriano ${ }^{32}$. Se assim for, Epicteto teria nascido por volta do ano 50 em Hierápolis (cujas ruínas localizam-se ao lado da atual Pamukkale, na Turquia), sítio famoso por suas fontes termais ${ }^{33}$, na época uma importante cidade da Frígia meridional situada aos pés do monte Mesogis, diante da Laodiceia. De acordo com Aélio Espartano ${ }^{34}$, Epicteto era amigo de Adriano, o que pode ser verdade, já que, em Diatribes III.13.4, Epicteto se refere positivamente à Pax Romana à qual Adriano estava intimamente associado. A partir desses cálculos e conjecturas, Schenk ${ }^{35}$ estima as datas de nascimento e morte de Epicteto entre 50 e 138, supondo que ele estaria vivo sob Adriano e morto antes dos 90 anos.

ter sido atingido por esse decreto. Cf. STELLWAG, 1933, p. 1 ss.; AULO GÉLIO, Noites Áticas 15.11; SIMPLÍCIO, Commentarius in Epicteti Enchiridion, 153 b; PLÍNIO O JOVEM, Cartas 3.11; TÁCITO, Agricola, c. 2; DUDLEY D. R. 1980, p. 139, nota 1; SHERWIN-WHITE, 1957, p. 126-30.

${ }^{29}$ Temístio viveu entre 317 e 387 e foi um filósofo peripatético tardio.

${ }^{30}$ Tito Fúlvio Aélio Antonino Augusto Pio nasceu em 19 de setembro de 86 e faleceu em 7 de março de 161. Governou Roma entre 138 e 161.

${ }^{31}$ Cf. TEMÍSTIO, Oraçóes 5, 63 d.

${ }^{32}$ Públio Aélio Trajano Adriano Augusto nasceu em 24 de janeiro de 76 e faleceu em 10 de julho de 138. Governou Roma entre 117 e 138.

${ }^{33}$ Que, aliás, funcionam até hoje.

34 AÉLIO ESPARTANO, Vida de Adriano 16.10, IN: Historia Augusta.

${ }^{35}$ SCHENKL, 1916, p. xv - xxxiii. 
Dobbin ${ }^{36}$, embora concordando que isso é consistente com as fontes, prefere, pela imprecisão delas, dizer simplesmente que Epicteto floresceu em 110.

Segundo $\mathrm{Millar}^{37}$, não há evidências claras de que Epicteto estivesse em Roma no reinado de Nero, embora o próprio Epicteto se refira a vários eventos que aconteceram então: a resposta do cínico Demétrio ${ }^{38}$ diante da ameaça de morte de Nero (Diatribes I.25.22), a discussão entre Pacônio Agripino $^{39}$ e Floro $^{40}$ sobre se este deveria participar do espetáculo teatral de Nero (Diatribes I.2.12-18), a execução de Laterano ${ }^{41}$ em 65 (Diatribes I.1.19), a conversa entre

${ }^{36}$ DOBBIN, 2008, p. xiii.

${ }^{37}$ MILLAR, 1965, p. 141

38 Demétrio foi um filósofo cínico de Corinto. Viveu sob Calígula, Nero e Vespasiano (37-71). Era amigo de Sêneca, que muitas vezes o elogia e cita (Cf. por exemplo: SÊNECA, Cartas a Lucílio, 20.9, 62.3, 67.14, 91.19). Calígula tentou suborná-lo com dois mil sextércios, sobre o que o cínico observou: 'Se ele quisesse me tentar, deveria ter feito tal oferecendome todo o seu reino' (Cf. SÊNECA, Dos Beneficios, 7.11).

${ }^{39}$ Pacônio Agripino foi um filósofo estoico do século I muito elogiado por Epicteto (Cf. Diatribes I.1.28-30). Sob Nero, foi acusado junto com Trásea e banido da Itália em 67.

${ }^{40}$ Géssio Floro foi procurador romano na Judeia entre 64 e 66.

41 Pláutio Laterano foi amante de Messalina, esposa do imperador Cláudio e, por este motivo, condenado à morte em 48. Entretanto, foi perdoado a pedido de seu tio Aulo Pláutio (general e político romano da primeira metade do século I, conquistador da Britânia e primeiro governador desta província). Laterano, enquanto cônsul em 65, participou da conspiração de Pisão e foi condenado à morte. Com firmeza e coragem, negou-se a denunciar seus colegas de conspiração. Ao ser decapitado, e sendo o primeiro golpe náo suficientemente forte para matá-lo, calmamente esticou novamente o pescoço à espera do próximo e fatal golpe (Cf. Tácito, Anais, $11.30 ; 36 ; 13.11 ; 15.49 ; 60)$. 
Trásea Peto ${ }^{42}$ e Musônio ${ }^{43}$ sobre seu exílio (Diatribes I.1.2627), a reação de Pacônio Agripino ao saber de seu exílio em 66 (Diatribes I.1.28-32). Para Millar, tudo o que podemos saber com certeza é que Epicteto estava em Roma no período dos imperadores Flavianos ${ }^{44}$, quando era amigo e discípulo de Rufo ${ }^{45}$. Epicteto menciona uma anedota de Rufo relativa à morte de Galba ${ }^{46}$ (Diatribes III.15.14) e se refere a uma conversa entre ele e Rufo acerca do incêndio do Capitólio em 69 (ou em 80 -cf. Diatribes I.7.32). Em outra oportunidade, fala sobre a crueldade de Epafrodito (Diatribes I.9.29-30). Epicteto cita também Eufrates ${ }^{47}$, discípulo de Musônio (Diatribes I.15.8; IV.8.17-20) e traz à baila uma conversa entre Helvídio Prisco ${ }^{48}$ e Vespasiano (Diatribes I.2.19-21;

${ }^{42}$ Públio Clódio Trásea Peto foi um senador romano do século I que se destacou por sua oposição a Nero e por sua ligação com o Estoicismo. Processado por Nero em 66, foi condenado à 'morte por livre escolha' (liberum mortis arbitrium). Tendo as veias de ambos os braços cortadas, morreu na presença de amigos e admiradores. Cf. TÁCITO, Anais, 34-5; Dion Cássio, 62.26.4).

${ }^{43}$ Quanto a Musônio, mais à frente falaremos sobre ele.

${ }^{44}$ Os imperadores Flavianos governaram Roma entre 69 e 96. São eles: Vespasiano (69-79) e seus filhos Tito (79-81) e Domiciano (81-96). Após Galba e Otão, Vitélio tornou-se imperador, em 69. Entretanto, algumas legióes estacionadas nas províncias declararam Vespasiano imperador. Vitoriosas na batalha de Bedriacum, as forças flavianas entraram em Roma em 20 de dezembro do mesmo ano, e Vespasiano foi declarado imperador pelo senado no dia seguinte.

${ }^{45}$ Cf. CORA LUTZ, 1947 , p. 8-9.

46 Sérvio Sulpício Galba César Augusto viveu entre 24 de dezembro de 3 e 15 de janeiro de 69 . Foi imperador romano por sete meses entre 68 e 69 .

${ }^{47}$ Eufrates foi um eminente filósofo estoico que viveu entre 35 e 118. Segundo Filostrato (Vida dos Sofistas Ilustres 1.7; Vida de Apolônio de Tiana 1.13), seria nativo de Tiro. Segundo Estêvão de Bizâncio (Ethinica 274.17), seria de Epifaneia, na Síria. Eunápio (Vida dos Filósofos e dos Sofistas 454), por sua vez, chama-o de egípcio. Muito elogiado por Plínio (Cartas 1.10), também é citado por Epicteto (Diatribes III.15; IV.8) e por Marco Aurélio (10.31). Cf. Dion Cássio 69.8.

${ }^{48}$ Helvídio Prisco foi um filósofo estoico e um político romano que viveu sob Nero, Galba, Otão, Vitélio e Vespasiano. Sob Nero foi questor 
cf. IV.1.123), a qual, se verdadeira, teria ocorrido entre 71 e $72^{49}$. Epicteto faz várias alusóes a cenas romanas, como o aqueduto Aqua Marcia (Diatribes II.16.30-1), o altar da Febre no Palatino (Diatribes I.19.6), cenas do circo ou do teatro (Diatribes I.11.27; I.29.37), da Saturnália ${ }^{50}$ (Diatribes I.25.8; I.29.31; IV.1.58), a libertação de um escravo diante do pretor (Diatribes II.1.26-7), o seu encontro com um cônsul nas ruas ${ }^{51}$ (Diatribes III.3.15 e 17) e a eleição de um tribuno (Diatribes I.19.24)

Quanto a Caio Musônio Rufo, professor de filosofia de Epicteto, que o menciona em Diatribes I.1.27 e I.9.29, observando que ainda era escravo enquanto aluno dele, Suidas nos diz ser ele um tirreno (etrusco), natural de Volsínios, um filósofo dialético e um estoico. Musônio foi filósofo ativo do reinado de Nero ao reinado de Trajano. Foi exilado por Nero e enviado para a ilha de Gyaros em $65^{52}$. Sua vida se estendeu de 30 a 90 ou 100, sobrevivendo até os Flavianos. Chegaram-nos, em parte, suas Diatribes, escritas por certo Lúcio. A edição crítica de sua obra é de autoria de Hense ${ }^{53}$,

da Acaia e tribuno das plebes (56). Restaurou a ordem e a paz na Armênia. Foi banido em 66 por sua declarada simpatia por Bruto e Cássio. Galba libertou-o do exílio em 68, mas logo foi novamente banido e, a seguir, executado por Vespasiano.

${ }^{49}$ Cf. MILLAR, 1965, p. 142.

${ }^{50}$ A Saturnália era um antigo festival romano em honra a Saturno que ocorria entre os dias 17 e 23 de dezembro (no calendário juliano). Havia, então, um sacrifício no templo de Saturno e um banquete público, seguido de troca de presentes. Durante as festividades, quebravam-se as normas: os senhores, por exemplo, serviam seus servos.

${ }^{51}$ Epicteto aparentemente primeiro agiu como Sócrates, questionando as pessoas pelas ruas, até levar um soco na cara de um rico ex-consul (Cf. Diatribes II.12.17 ss.).

52 Cf. TÁCITO, Anais xv, 71; Diatribes I.25.19-20; II.6.22; III.24.100 e 109 .

53 HENSE, Musonii Rufi Reliquiae. Leipzig 1905. Outros trabalhos importantes e recentes que tratam de Musônio são: LAURENTI. Musonio, maestro di Epitteto. IN: $A N R W$ 2.36.3, 1989, p. 2105-2146; 
que deve ser complementada por um papiro incluído na edição de Cora Lutz ${ }^{54}$.

Depois de ser aluno de Rufo, Epicteto tornou-se filósofo-orador nas ruas de Roma (cf. Diatribes II.12.17-25). Após ter sido expulso de Roma por Domiciano, Epicteto retirou-se para Nicópolis ${ }^{55}$, cidade localizada na entrada do golfo Ambrácico, no Épiro, fundada por Augusto em comemoração à sua vitória na batalha de Actium ${ }^{56}$. Havia duas províncias com o nome de Épiro: Epirus Vetus (Épiro Velha) e Epirus Nova (Épiro Nova), ambas estabelecidas sob Domiciano e conhecidas até a era bizantina. Nicópolis, ao contrário do que anuncia a Suda, era a capital de Epirus Vetus, e Dirráquio era a capital de Epirus Nova.

É possível que Epicteto tenha recebido a visita de Adriano em Nicópolis ou o tenha conhecido em Atenas. Souilhé ${ }^{57}$, porém, argumenta que os textos de Filostrato e Luciano citados por Schenk ${ }^{58}$ nada provam quanto a isso e que a passagem das Diatribes (III.21) a partir da qual se depreende que Epicteto tinha conhecimento dos mistérios de Elêusis náo constituem prova de que Epicteto tenha efetivamente viajado para Atenas.

FRANCIS, J. A. Subversive virtue: asceticism and authority in the secondcentury pagan world. University Park: Pennsylvania State University Press. 1995, p. 11-16.

${ }^{54}$ Um artigo de Aldo Dinucci com a traduçáo bilíngue dos Fragmentos Menores de Musônio junto com uma biografia detalhada do filósofo romano encontra-se disponível em: http://dx.doi.org/10.1590/S010131732012000300015

55 Onde fundou sua escola. Cf. AULO GÉLIO, Noites Áticas 15.11; SIMPLÍCIO, Commentarius in Epicteti Enchiridion, 65.37.

${ }^{56}$ Batalha naval, ocorrida em 2 de setembro de 31 a.C., que decidiu a Guerra Civil Romana, dando fim à República. Nessa batalha, Otaviano (mais tarde César Augusto) enfrentou as forças combinadas de Marco Antônio e Cleópatra VII - e sagrou-se vencedor.

57 SOUILHÉ, 2002, p. viii, nota 3.

${ }^{58}$ SCHENKL, 1916, p. xxvi. 
Epicteto foi influenciado pela resistência de alguns estoicos (Helvídio Prisco entre outros) aos imperadores romanos Nero, Vespasiano e Domiciano, na segunda metade do primeiro século (cf. Diatribes I.1.18-32; I.2.1924). O aspecto político do ensino de Epicteto poderia ter sido considerado subversivo (cf. Diatribes I.29.9), e possivelmente essa é a razão pela qual Arriano ${ }^{59}$ não publicou espontaneamente as Diatribes e o Encheiridion.

59 Lúcio Flávio Arriano Xenofonte viveu entre 86 e 160. Cidadão romano de origem grega e aluno de Epicteto, Arriano compilou as aulas de seu professor em oito livros (As Diatribes de Epicteto), dos quais quatro sobrevivem, e redigiu o Encheiridion (Cf. à frente a seção 'A quem se destina e para que serve o Encheiridion de Epicteto'). Apesar disso, a autoria das obras é tradicionalmente atribuída a Epicteto, pois se considera, desde a Antiguidade, que seu conteúdo representa fielmente o pensamento epictetiano (possivelmente essa é a razáo pela qual a Suda nos diz que Epicteto escreveu muitos livros). Quanto a isso, vejamos, em nossa tradução, o que nos fala o próprio Arriano em carta que prefacia as Diatribes: "(1) Nem compus os discursos de Epicteto (como se alguém pudesse escrever tais coisas!) nem eu mesmo, que digo não tê-los escrito, os expus aos homens. (2) Quantas coisas ouvi-o dizer, essas mesmas tentei, escrevendo como me era possível, guardar com cuidado para mais tarde para mim mesmo - as lembranças de seu pensamento e de sua franqueza ao falar (parrhesia). (3) São de qualidade tal como seria conveniente que alguém, tendo-os preparado para si mesmo, os lesse para outro homem, (4) mas não são tais que alguém os compusesse para que outros os encontrassem posteriormente. (5) Porém, não sei como (não tendo eu consentido, nem tendo eu conhecimento), esses escritos escaparam para os homens. Se não pareço compô-los de modo conveniente, náo muito me justifico; e nem minimamente Epicteto, se alguém desprezar suas palavras, já que digo aos homens que nenhuma outra motivaçáo era evidente nele, (6) senão mover o pensamento dos ouvintes para o que há de melhor. (7) Se então esses mesmos discursos puderem realizar isso, possuiriam tal propriedade, penso eu, porque é necessário que as palavras dos filósofos assim o sejam. Caso contrário, saibam os que se depararem com esses discursos que o próprio Epicteto, quando os pronunciava, necessariamente comovia o ouvinte, precisamente porque desejava comovê-lo. (8) Se os discursos por si mesmos não realizarem isso, quis a fortuna ser eu o responsável, quis a fortuna ser assim necessário. Adeus!" 
O reconhecimento de Epicteto na Antiguidade é testemunhado por Favorino ${ }^{60}$, protegido de Adriano ${ }^{61}$. Aulo Gélio também nos informa ${ }^{62}$ que Herodes Ático ${ }^{63}$ considerava Epicteto como o maior dos estoicos, o que indica que os textos de Epicteto circulavam após sua morte e que Epicteto já era então renomado. Marco Aurélio ${ }^{64}$ exaltou Epicteto diversas vezes e chegou a colocá-lo ao lado de Crisipo e Sócrates. Galeno ${ }^{65}$, contemporâneo de Marco Aurélio, escreveu um livro ${ }^{66}$ (hoje perdido) no qual defendia Epicteto das críticas de Favorino. Por Orígenes ${ }^{67}$, Epicteto é citado seis vezes, sendo particularmente interessante uma passagem de Contra Celsum ${ }^{68}$, na qual nos diz que Epicteto era mais popular em seus dias que Platão. No século VI, Simplício e seu comentário atestam a continuidade do renome de Epicteto.

Epicteto viveu na pobreza tanto em Roma quanto em Nicópolis. Ao final da vida tomou uma serva para ajudá-lo

60 Favorino de Arelate viveu entre 80 e 160 e foi um sofista e um filósofo romano. Floresceu sob Adriano. Uma vez, após deixar-se vencer por um argumento facilmente refutável de Adriano, disse que era tolice criticar a lógica do mestre de trintas legióes. Foi banido pelo próprio Adriano para a ilha de Quios por volta de 130. Retornou a Roma sob Antonino Pio.

${ }^{61}$ Cf. AULO GÉLIO, Noites Áticas 17.19.1-6.

${ }^{62}$ AULO GÉLIO, Noites Áticas 1.2.6.

63 Heródes Ático viveu entre 101 e 177. Aristocrata grego, chegou a ser senador e cônsul em Roma (em 143, sob Antonino Pio). Destacouse como sofista, sendo talvez o maior representante da Segunda Sofística. Construiu, com seus próprios recursos, diversas instalações públicas, entre teatros, aquedutos e estádios.

${ }^{64}$ MARCO AURÉLIO, 7.19.

${ }^{65}$ Aélio Galeno ou Cláudio Galeno, também conhecido como Galeno de Pérgamo (atual Bergama, na Turquia), viveu entre 129 e 200-216 e destacou-se como médico, cirurgião e filósofo.

${ }^{66}$ Cf. GALENO, De libris Propriis 11.

67 Orígenes Adamâncio viveu entre 184/185 e 253/254 e foi um teólogo cristão.

68 ORÍGENES, Contra Celsum, 6.2. 
a criar um menino que ele adotara, pois a criança iria ser exposta pelo pai que se encontrava em extrema miséria ${ }^{69}$.

\section{A QUEM SE DESTINA E PARA QUE SERVE O ENCHEIRIDION DE EPICTETO}

O termo grego encheiridion se diz do que está à mão, sendo equivalente ao termo latino manualis, "manual" em nossa língua. Significa também "punhal” ou "adaga", equivalente ao latino pugio, arma portátil usada pelos soldados romanos atada à cintura. Simplício, no proêmio de seu Comentário ao Encheiridion de Epicteto, diz-nos que Arriano sintetizou as coisas mais importantes e necessárias em filosofia a partir das palavras de Epicteto para que estivessem à vista e à mão (1.05-1.35). Assim, o Encheiridion serve não como uma introdução aos que ignoram a filosofia estoica, mas antes àqueles já familiarizados com os princípios do Estoicismo, para que tenham uma síntese que possam sempre levar consigo e utilizar. Tal uso se relaciona à tradição estoica da meditação diária, para o que o Encheiridion serviria de guia e inspiração. Epicteto discorre sobre esse tema nas Diatribes em diversas ocasióes (I.1.25; I.27.6 ss.; II.1.29; III,10,1). Marco Aurélio Antonino, cuja obra póstuma, as Meditaçóes, consiste justamente nessa atividade, compara os princípios da filosofia com os instrumentos da medicina, afirmando que "os médicos, que sempre têm à mão os instrumentos de sua arte, devem ser imitados" (III.13; cf. IV.3). Sêneca se refere à prática da meditação diária na Carta a Lucílio XCIV e em Dos

69 SIMPLÍCIO, Commentarius in Epicteti Enchiridion, 44.77.80. Alguns comentadores creem Epicteto ter, entáo, tomado uma esposa. Entretanto, por meio de uma anedota, Luciano (Cf. Vida de Demonax, 55) parece indicar que Epicteto jamais se casou. 
Beneficios VII, 1. Cícero se refere igualmente a essa prática no De Finibus (III.7).

Ainda no proêmio de seu Comentário (1.10 1.40), Simplício menciona uma carta - que prefaciava, na Antiguidade, o Encheiridion - de Arriano a certo Messaleno. De acordo com Simplício, tal carta asseverava que o objetivo do Encheiridion é, ao encontrar pessoas capazes de serem persuadidas por ele, não apenas afetá-las através das palavras, mas fazer com que de fato apliquem às suas vidas as ideias contidas nele, tornando livres suas almas. Simplício afirma que as palavras do Encheiridion são efetivas, capazes de agitar a alma de qualquer um que não esteja totalmente mortificado.

Simplício observa também que, na perspectiva epictetiana, a alma deve libertar-se das emoçóes irracionais e que as coisas externas devem ser usufruídas de modo consistente com o bem genuíno (1.40 - 1.45). Uma das características do pensamento epictetiano notadas por Simplício é que quem o póe em prática pode alcançar a felicidade sem a promessa de recompensa post mortem para a virtude. Como salienta Simplício:

Mesmo supondo-se a alma mortal e destrutível junto com o corpo, ainda assim [...] qualquer um que viva de acordo com esses preceitos será genuinamente feliz [...] já que terá atingido sua própria perfeição e alcançado o bem que lhe é próprio. (2.05-2.10)

Simplício, notando que as palavras do Encheiridion são enérgicas e gnômicas, mantendo entre si certa relação e ordem lógica, objetivando a arte que retifica a vida humana e elevando a alma humana ao seu próprio valor (2.15 ss.), 
observa que o Encheiridion não se remete nem ao asceta, nem ao homem teórico, que se distanciam das coisas do corpo, mas visa o homem que tem o corpo como um instrumento e que deseja ser um genuíno ser humano, almejando reconquistar a nobreza de sua ancestralidade, com a qual Deus agraciou os homens. Quanto a isso, diz-nos Simplício:

Alguém assim deseja ardentemente que sua alma racional viva como ela é por natureza, governando o corpo e transcendendo-o, usando-o não como uma parte coordenada, mas como um instrumento. (2.35-2.40)

Simplício (3.1 ss.) ressalta ainda que, no Encheiridion, Epicteto parte da tese sustentada por Sócrates no Primeiro Alcibiades (I 129 c7), segundo a qual o genuíno ser humano é uma alma racional que usa o corpo como um instrumento. Simplício assim formaliza tal argumento de Sócrates no Primeiro Alcibiades:

O homem usa suas mãos para trabalhar;

Quem usa algo se distingue daquilo que usa como instrumento;

Ora, é necessário que o homem seja ou o corpo, ou a alma, ou combinação de ambos. Mas se a alma governa o corpo e não o contrário, o homem não é o corpo e nem, pela mesma razão, é a combinação de ambos.

Disso decorre que o corpo não se move por si mesmo e é um cadáver, pois é a alma que o move;

Consequentemente, o corpo tem status de instrumento em relação à alma. 


\section{RECEPÇÃo E TRANSMISSÁO DO ENCHEIRIDION DE EPICTETO: DA ERA BIZANTINA AOS NOSSOS DIAS}

Entre os bizantinos é tangível o prestígio do Encheiridion: três paráfrases cristãs nos chegaram, uma falsamente atribuída a Nilo, outra conhecida como Paraphrasis Christiana e outra que se encontra no manuscrito Vaticanus gr. 2231. Aquela do Pseudo-Nilo (em cujo texto falta o nome do autor) foi atribuída a Nilo porque em alguns códices tal opúsculo aparece entre as obras deste último (cf. códice Vaticanus Ottobonianus gr. 25, lavrado entre 1563 e 1564). Ignora-se quando tal opúsculo foi composto. $\mathrm{O}$ texto mais antigo, presente no códice Marcianus gr. 131, foi lavrado no século XI. A Paraphrasis Christiana foi composta algum tempo antes do ano 950. O Encheiridion Christianum foi descoberto por Spanneut no códice Vaticanus gr. 2231, lavrado entre os anos 1337 e $1338^{70}$.

A história da difusão do texto do Encheiridion de Epicteto na Europa começa na Renascença Italiana. Niccolò Perotto (1430-1480) foi o primeiro a verter o Encheiridion para o latim, em 1450. Perotto estava ligado ao cardeal Bessarion, cristão bizantino que, tendo chegado a Roma e se convertido ao catolicismo, trouxe consigo os tesouros culturais de sua terra natal, assim como o anseio de fazê-los conhecidos dos europeus. Perotto foi incumbido dessa tarefa no que se refere a Epicteto e traduziu o Encheiridion tal como nos é apresentado por Simplício em seu Comentário. Há uma excelente edição moderna desta tradução ${ }^{71}$.

Após Perotto, Ângelo Poliziano (1454-1494) realizou uma tradução do Encheiridion que, publicada em 1497,

\footnotetext{
${ }^{70}$ Cf. SPANNEUT, 1972, p. 49-57.

71 OLIVER PENDLETON, 1954.
} 
tornar-se-ia extremamente influente ao longo dos séculos seguintes. Poliziano era um protegido dos Médicis, tendo acesso à famosa biblioteca de Lourenço de Médici, a quem dedicou e presenteou a referida tradução em 1479 . Sendo um entusiasta da Renascença, Poliziano percebeu em Epicteto uma mensagem filosófica compatível com aqueles dias: o desenvolvimento autônomo da alma racional. Poliziano tinha em mãos dois manuscritos incorretos e com muitas lacunas. Ao perceber que havia ainda mais manuscritos assim, corrigiu o texto tomando por base o Comentário de Simplício. Em sua tradução, o Encheiridion é dividido em três partes: uma que trata da divisão entre o que está e o que não está sob nosso encargo, outra dedicada aos homens que progridem moralmente através da filosofia estoica e outra que trata dos deveres. A versão de Poliziano dominou a primeira parte do século XVI. Essa tradução de Poliziano pode ser encontrada na excelente traduçáo italiana do Encheiridion de Epicteto realizada por Enrico Maltese ${ }^{72}$.

Em 1535, Trincavelli, um médico humanista toscano, publicou uma edição em grego do Encheiridione das Diatribes, objetivando difundir a obra de Epicteto. O Encheiridion de Trincavelli baseia-se em duas ediçóes idênticas do texto grego que haviam sido recentemente publicadas: uma de 1529, de Haloander, em Nuremberg, e outra de 1531, de Cratander, em Bâle.

Em 1546, o gramático Caninius, que lecionou em Pádova e Roma e posteriormente se transferiu para a França, publicou, em Veneza, o Comentário ao Encheiridion, de Simplício. Antes dele, porém, algumas edições do Encheiridion haviam sido lançadas em solo francês: as duas de Neobarius (1540), uma contendo o texto em grego do

${ }^{72}$ MALTESE, 1990. 
Encheiridion e outra com o texto em grego e a tradução de Poliziano, e aquela de certo professor de grego chamado Tusanus ou Toussaint (1552), ligado ao círculo de Erasmo de Roterdã, que reeditou a versão do texto em grego apresentada por Neobarius. A tradução de Poliziano chegaria à Alemanha, publicada pelo humanista e helenista Jacobus Scheggius, em 1554. Em 1560 Hieronymus Wolf publicou sua versão latina do Encheiridion, que se tornou popular, ganhando reimpressôes até o século XVIII.

Em 1605, um missionário jesuíta postado na China de nome Matteo Ricci publicou uma traduçáo de parte do Encheiridion em ideogramas chineses por ver em Epicteto uma ponte entre o pensamento cristáo e o confuciano ${ }^{73}$.

No século XVI começaram a surgir as primeiras traduçôes em línguas vernáculas do Encheiridion. Oldfather ${ }^{74}$ sugere que a mais antiga dessas traduções é a de Jacob Schenk (Basileia, 1534), que, tomando a edição latina de Poliziano, verteu o Encheiridion para o alemão ${ }^{75}$. Antoine du Moulin foi o primeiro a publicar uma tradução francesa da obra em 1544. Ao invés de traduzir o texto grego, Moulin também se apoiou na versão latina de Poliziano. Talvez seja essa tradução à qual se refere Rabelais, quando, no livro II de Pantagruel $^{6}$, afirma que "Vejo Epicteto elegantemente vestido à francesa".

Após Moulin, temos a tradução de 1567 do cristáo neoestoico Rivaudeau, nobre por origem e protestante. Guillaume du Vair foi o próximo a traduzir o Encheiridion, publicando seu trabalho em 1591, uma traduçẫo que se

${ }^{73}$ Cf. SPALATIN, 1975, p. 226

${ }^{74}$ Oldfather, 1952, p. 194-6.

75 Essa edição, de 1534, é extremamente rara. Oldfather conseguiu localizar apenas um exemplar no British Museum, exemplar do qual ele oferece um fac-simile ao final de seu Contributions toward a bibliography of Epictetus (1927).

${ }^{76}$ RABELAIS, 2008, p. 226. 
tornou clássica, com uma linguagem afeita ao século XVII francês. Vair, um neoestoico que escreveu outras obras influentes sobre o Estoicismo ${ }^{77}$, foi o primeiro católico a traduzir o Encheiridion para o francês ${ }^{78}$.

Em italiano, destaca-se sobretudo a versão de vulgarização do poeta Giacomo Leopardi ${ }^{79}$, que não a publicou em vida. Tendo concluído sua versão em 1825 e confiado os manuscritos ao seu editor, seu trabalho só foi publicado, juntamente com um prefácio do poeta, em 1854. Tal versão também pode ser encontrada na edição de Maltese do Encheiridion já citada acima.

Em nossa língua, temos notícia apenas de três traduçóes do Encheiridion: uma de 1959, outra de 2007, além de uma antiga edição portuguesa de 1785, realizada por Antonio de Souza, bispo de Vizeu e filho do célebre Martim Afonso de Sousa. Na introdução da obra (1785, p. iii), somos informados que tal tradução foi originalmente publicada anonimamente em 1594, com segunda ediçấo em 1595. Passaram-se entâo cento e noventa anos até que a terceira edição viesse à luz, através de certo Luiz Antonio de Azevedo.

No século $\mathrm{XX}$, multiplicaram-se as traduçóes em línguas modernas do Encheiridion de Epicteto, entre as quais se destacam as de Gourinat (1998), Boter (1999), Oldfather (1928), White (1983), Hadot (2000), Maltese (1990) e García (1995).

77 Como La Sainte Philosophie e De La Constance e La Philosophie Morale dês Stoiques. Cf. DU VAIR, 1625.

78 Cf. BROOKE, 1999, p. 9.

79 Poeta italiano. Viveu entre 1798 e 1837. 
SOBRE A DIVISÃo EM CAPítulos do ENCHEIRIDION DE EPICTETO:

Boter $^{80}$ observa que há três modos básicos de dividir o texto do Encheiridion: o inaugurado pela edição de Haloander (1529), que divide o texto em 62 capítulos; o introduzido por Wolf (1560), que divide o texto em 79 capítulos; e o de Upton (1741), que divide o texto em 52 capítulos. Este último é seguido por Schweighäuser, que divide ainda o capítulo 50 em dois, perfazendo ao todo 53 capítulos (tal é a divisão que prevalece em todas as ediçóes subsequentes). Boter mantém a divisão em números de Schweighäuser, embora subdividindo quatro capítulos em dois (capítulos 5 , $14,19,48)$. Boter observa que a subdivisão do capítulo 5 é sustentada de modo unânime pela tradição, que a subdivisão do capítulo 14 é sustentada por Simplício, que a subdivisão do capítulo 19 é sustentada por quase toda a tradição, e que apenas por Simplício o capítulo 48 é apresentado como um único. $\mathrm{O}$ capítulo 33 constitui um caso especial: embora muitas de suas seçóes sejam apresentadas como capítulos diferentes em diversos manuscritos, Boter, por considerar tratar-se tal capítulo de um todo coerente, apresenta-o como um só.

\section{O estabelecimento do texto grego}

A edição do texto estabelecido por Gerard Boter do Encheiridion de Epicteto preenche uma lacuna de séculos quanto aos estudos epictetianos. $\mathrm{O}$ texto foi pela primeira vez editado em grego por Haloander em 1529, seguido por Hieronymus Wolf em 1560, ediçóes estas que foram tomadas como parâmetro pelos estudiosos nos dois séculos seguintes.

${ }^{80}$ Boter, 1999, p. 146-7. 
Em 1741 Upton constituiu novo texto. Schweighäuser publicou a primeira edição corrigida do texto grego do Encheiridion em 1798. O próximo a trabalhar na constituição do texto do Encheiridion foi Schenkl, cuja edição de 1916 foi adotada pelos estudiosos nas décadas seguintes. Schenkl, porém, após o gigantesco trabalho de estabelecer o texto das Diatribes, não desejou dedicar-se a fazer uma edição crítica do Encheiridion.

Segundo Boter ${ }^{81}$, o grande número de manuscritos, as paráfrases cristâs e o Comentário de Simplício desencorajaram os estudiosos quanto a constituir tal edição crítica. Essa tarefa foi levada a cabo pelo próprio Gerard Boter em livro publicado em 1999.

Boter partiu de sete fontes principais para o estabelecimento do texto do Encheiridion:

1. Os códices que contêm o texto do Encheiridion;

2. Os códices que contêm o Comentário de Simplício;

3. Os títulos contidos em alguns códices do Comentário de Simplício;

4. Os títulos suplementares contidos em alguns códices do Comentário de Simplício;

5. Os trechos das Diatribes dos quais Arriano fez sínteses que adicionou ao Encheiridion;

6. Citaçóes do Encheiridion feitas por autores antigos de séculos posteriores;

7. As três paráfrases cristãs.

Segundo Boter ${ }^{82}$, há exatamente 59 códices contendo o Encheiridion, sendo que nenhum deles é anterior ao século $\mathrm{XIV}$. Os códices contendo as paráfrases cristãs são bem mais antigos: alguns datam dos séculos X (Laurentianus 55,4 e Parisinus gr. 1053) e XI (Nili Encheiridii Codex Marcianus

${ }^{81}$ Idem, 2007, p. vi.

${ }^{82}$ Idem, ibidem, p. vii. 
gr. 131), o que evidencia que, durante o período bizantino, as paráfrases cristãs despertavam mais interesse que o próprio Encheiridion de Epicteto.

Entre os mais antigos códices contendo o Encheiridion de Epicteto estão os seguintes: o Parisinus suppl. gr. 1164, o Vaticanus gr. 1950 (que contém apenas os três primeiros capítulos) e o Oxoniensis Canonicianus gr. 23 (que possui apenas fragmentos). Os códices do Encheiridion de Epicteto dividem-se em duas famílias: uma que conta apenas com o Atheniensis 373 e outra que engloba todos os demais. A primeira família é complementada pelos títulos supridos pelo códice Vaticanus gr. 327, no qual se encontra o Comentário de Simplício.

Quanto aos códices do Comentário de Simplício, remetemos o leitor a Ilsetraut Hadot, que realizou uma edição crítica de tal obra (1996). Boter observa que Simplício, ao comentar Epicteto, nem sempre é fiel aos termos que este último utiliza, do que se conclui que, embora não se deva negligenciar o testemunho de Simplício, é preciso utilizá-lo com cautela ${ }^{83}$.

Quanto aos títulos presentes em alguns códices do Comentário de Simplício, Boter informa que, originalmente, apenas o início dos capítulos era posto à frente de cada comentário. Porém, em alguns códices, nos dois primeiros capítulos encontra-se o texto da Paraphrasis Christiana; no terceiro, os textos do Encheiridion e da Paraphrasis Christiana se confundem - e daí em diante aparece somente o texto do Encheiridion, cuja fonte é a mesma do códice Atheniensis 373.

Além dessas fontes, temos os livros das Diatribes de Epicteto, a partir das quais, como já observamos acima, Arriano confeccionou o Encheiridion.

83 Idem, ibidem, p. ix. 
Entre os autores posteriores que são fontes para o estabelecimento do texto do Encheiridion destaca-se Estobeu, que cita Epicteto abundantemente.

Há também autores patrísticos, entre os séculos II e VI, que tratam do Encheiridion, como Eusébio, Ambrósio, Basílio Magno, Dorotheus de Gaza, Procópio de Gaza e Sinésio. Estes últimos autores em nada contribuem para o estabelecimento do Encheiridion, exceto no que se refere ao oitavo capítulo, discutido por Basílio, Dorotheus e Procópio.

Entre os neoplatônicos, além de Simplício, são especialmente relevantes os comentários a Platão de Olimpiodoro e Proclo. Também outros autores antigos (como Luciano, Dion Crisóstomo e Antônio Magno) e autores árabes (como $\mathrm{Al}$-Kindi e Ibn Fatik ${ }^{84}$ ) são utilizados para estabelecer o texto do Encheiridion.

Por fim temos as três paráfrases cristâs do Encheiridion de Epicteto já mencionadas acima. Quanto a elas, acrescentemos que a paráfrase do Pseudo-Nilo consiste no Encheiridion com uma série de interpolaçóes, sobretudo nos capítulos onde Epicteto afirma teses contrárias à ortodoxia cristã (capítulos 32, 33 e 52). O autor também substitui os exempla de Epicteto por nomes cristáos (como "Paulo" no lugar de "Sócrates" no capítulo 51). Também hoi theoi (os deuses) é substituído por ho Theos (o Deus) ao longo do texto. Mencionemos também que os códices da Paraphrasis Christiana dividem-se em duas famílias, das quais uma consiste somente no códice Laurentianus 55.4 e a outra, nos demais.

Seguimos em nossa tradução o texto estabelecido por Boter. Cotejamos nosso trabalho com as melhores traduçóes disponíveis, dando especial atenção às de Gourinat (1998),

${ }^{84}$ Cf. JADAANE, 1968. 
Boter (1999), Oldfather (1928), White (1983), Hadot (2000), Maltese (1990) e García (1995). 
(Página deixada propositadamente em branco) 


\section{ENCHEIRIDION DE EPICTETO}


(Página deixada propositadamente em branco) 


\section{[1.1] Das coisas existentes, algumas são encargos}

nossos ${ }^{1}$, outras não. São encargos nossos o juízo ${ }^{2}$, o impulso ${ }^{3}$, o desejo ${ }^{4}$, a repulsa ${ }^{5}$ - em suma: tudo quanto seja ação nossa.

${ }^{1}$ A expressão ephi hemin não tem equivalente direto que possa dar conta de seu significado em nossa língua, mas possui imagem concreta e clara, referindo-se a algo que é colocado sobre nós, sustentado por nós, pois nos encontramos embaixo, fornecendo seu apoio. A opçáo por 'encargo nosso' acentua a ideia de responsabilidade que temos quanto a isso que está sobre nós (e do que somos a causa primária). A expressáo é diferentemente vertida por diferentes tradutores. Oldfather (1928) a traduz por 'things under our control'; White (1983), por 'what is up to us'; Gourinat (1998), por 'choses qui dépendent de nous'; Cf. Diatribes I.22.10; II.6.8; II.9.15; II.19.13; IV.1.65 ss.

${ }^{2}$ Hypolepsis: substantivo relacionado ao verbo hypolambano, expressa a ideia de sucessão e de substituição, adquirindo os sentidos de 'réplica, resposta, concepção e pensamento'. O vocábulo 'juízo', empregado aqui para traduzir essa noção, deve ser entendido como um parecer ou uma opiniáo que orienta nossa conduta diante de um acontecimento que se nos apresenta. Quanto ao conceito, Schweighäuser observa que 'em sua própria origem e forma significa uma ação de nossa mente, a recepção de uma opinião e sua admissão em nosso espírito' (1799 (vol. 3), p. 141). Oldfather (1928) traduz hypolepsis por 'conception'; White (1993), por 'opinion'; Gourinat (1998), por 'jugement'; e García (1995), por 'juicio'.

${ }^{3}$ Horme: substantivo relacionado ao verbo ornumi ('levantar-se'), designa o primeiro bote de um assalto ou ataque, adquirindo os sentidos de elã e de impulso. Entre as traduçóes consultadas para este trabalho, a única exceção a 'impulso' como vocábulo para traduzir horme é a opção de Oldfather (1928), que emprega 'choice' ('escolha'). Horme deve ser entendido, no contexto do pensamento epictetiano, como o ímpeto para a ação, a tendência para agir desta ou daquela maneira diante de determinada coisa. Schweighäuser define o conceito como o 'ímpeto para agir que recebemos de nossa própria escolha’ (1799 (vol. 3), p. 141).

${ }^{4}$ Orexis é o nome da ação do verbo orego, que apresenta o significado de 'estender ou tender na direçấo de algo' (por exemplo: estender as máos para o céu ou para pedir algo a alguém), de onde 'desejo', 'apetite'. Uma forma de apreender da maneira mais precisa possível seu significado é ter em conta que orexis se opóe a ekklisis, que expressa o movimento contrário, o de afastar-se (Cf. nota seguinte). Para Epicteto, desejamos as coisas que consideramos boas (cf. Diatribes I.4.2-3).

5 Ekklisis identifica a ação de declinar, expressando o movimento contrário de klisis, que significa a ação de inclinar-se. O termo, na litertatura grega, é empregado para descrever o movimento da tropa que evita o combate ou para descrever o declínio de um astro. Oldfather (1928), 
Não são encargos nossos o corpo, as posses, a reputação, os cargos públicos - em suma: tudo quanto não seja ação nossa. [1.2] Por natureza, as coisas que são encargos nossos são livres $^{6}$, desobstruídas ${ }^{7}$, sem entraves ${ }^{8}$. As que não são encargos nossos são débeis ${ }^{9}$, escravas, obstruídas ${ }^{10}$, de outrem ${ }^{11}$. [1.3] Lembra então que, se pensares ${ }^{12}$ livres as coisas escravas por natureza e tuas as de outrem, tu te farás entraves ${ }^{13}$, tu te afligirás ${ }^{14}$, tu te inquietarás ${ }^{15}$, censurarás tanto os deuses

White (1983) e Gourinat (1998) optaram traduzi-lo por 'aversão'; García (1995), por 'rechazo'. No Aurélio, 'aversão' apresenta os significados de 'ódio, rancor, antipatia', que não cabem no presente caso. Escolhemos traduzi-lo por 'repulsa' para expressar a ideia de repelir, afastar ou evitar algo, sem a conotação de aversão. Para Epicteto, repudiamos as coisas que consideramos ruins (Cf. Diatribes I.4.2-3).

6 Eleutheros: livre por oposiçáo a escravo. Para Epicteto, quem deseja o que náo é encargo seu necessariamente torna-se escravo, pois voluntariamente submete-se aos que podem proporcionar-lhe ou impedirlhe o acesso à coisa desejada (Cf. Diatribes I.4.19).

${ }^{7}$ Akolytos: adjetivo verbal de privação da ação relacionada ao verbo kolyo, que significa "afastar, desviar", aquirindo o sentido de "impedir". Bailly (2000) apresenta o substantivo neutro kolyon com o significado de 'obstáculo', 'impedimento'. Assim, akolutos refere-se a algo para o que não há impedimento quanto à sua obtenção, sendo, portanto, 'desimpedido'.

8 Aparapodistos: optamos traduzir o termo por 'sem entraves', pois trata-se de um adjetivo verbal que nega a açáo relacionada ao verbo podizo, que significa 'sujeitar os pés com travas', referindo-se principalmente a armadilhas para animais. Cf. o substantivo feminino podistra, que pode significar tanto 'armadilha que prende pelos pés' (Cf. Antologia Palatina 6, 107) quanto 'teia de aranha' (Cf. Antologia Palatina 9, 372).

9 Asthenes: privado de força, no sentido de 'força física, vigor'.

${ }^{10}$ Kolytos.

${ }^{11}$ Arriano assim relaciona os adjetivos empregados para qualificar o que é encargo nosso e o que não é: o que é encargo nosso é livre, desobstruído, sem entraves; o que não é encargo nosso é débil, escravo, de outrem.

12 Oiomai: 'pensar', no sentido de 'presumir', referindo-se a coisas incertas - daí 'pressentir, crer, estimar'.

${ }^{13}$ Empodizo significa literalmente 'meter os pés em uma armadilha'.

${ }^{14}$ Pentheo: verbo relacionado ao substantivo penthos, que significa 'dor, afliçấo'.

15 Tarasso: significa primariamente 'remexer', 'agitar', no sentido concreto de preparar um medicamento agitando os ingredientes que o 
como os homens. Mas se pensares teu unicamente o que é teu, e o que é de outrem, como o é, de outrem, ninguém jamais te constrangerá ${ }^{16}$, ninguém te fará obstáculos, não censurarás ninguém, nem acusarás quem quer que seja, de modo algum agirás constrangido, ninguém te causará dano ${ }^{17}$, não terás inimigos, pois não serás persuadido em relação a nada nocivo. [1.4] Então, almejando coisas de tamanha importância, lembra que é preciso que não te empenhes de modo comedido, mas que abandones completamente algumas coisas e, por ora, deixes outras para depois. Mas se quiseres aquelas coisas e também ter cargos e ser rico, talvez não obtenhas estas duas últimas, por também buscar as primeiras, e absolutamente não atingirás aquelas coisas por meio das quais unicamente resultam a liberdade e a felicidade $^{18}$. [1.5] Então pratica dizer prontamente a toda representação ${ }^{19}$ bruta $^{20}$ : "És representação e de modo algum

compóem.

${ }^{16}$ Anankazo: 'forçar', 'constranger'.

${ }^{17}$ Cf. abaixo, capítulo 30 e Sêneca, Da Constância do Sábio, 5.

${ }_{18}$ Felicidade traduz eudaimonia. No contexto do paganismo grego, daimonios é um adjetivo que qualifica tudo o que provém da divindade ou é enviado por um deus. Associado ao prefixo 'eu' ('bem', 'bom'), esse vocábulo tem significação próxima à de 'bem-aventurança' na acepção cristá.

${ }^{19}$ A concepção de Crisipo sobre a phantasia é que ela tem duas facetas: uma sensível (pois trata-se de uma modificação da faculdade diretriz) e outra virtual (pois a essa modificação é afixado um juízo, que descreve e avalia aquilo que efetuou a modificaçáo). Assim sendo, parece-nos que a palavra 'representação' (que possui, de acordo com o dicionário Aurélio, o sentido filosófico geral de 'conteúdo concreto apreendido pelos sentidos, pela imaginação, pela memória ou pelo pensamento') serve para o nosso propósito e por ela traduziremos phantasia.

${ }_{20}$ Trata-se do adjetivo trachys, apresentado por Bailly (2000) com o significado de 'rude', adquirindo diversos sentidos, dependendo do substantivo ao qual esteja ligado. 'Áspero', ao se tratar de uma pedra; 'pedregoso', ao se referir a um rio ou a um terreno; 'rouca', ao qualificar um tipo de voz; 'grosseiro, duro, cruel, violento e irascível', ao se referir ao comportamento de alguém. Simplício (Comentário ao Encheiridion 
<és> o que se afigura" ${ }^{21}$. Em seguida, examina-a e testa-a com essas mesmas regras que possuis, em primeiro lugar e principalmente se é sobre coisas que são encargos nossos ou não. E caso esteja entre as coisas que náo sejam encargos nossos, tem à mão que: "Nada é para mim"22.

[2.1] Lembra que o propósito $^{23}$ do desejo é obter o que se deseja, <e> o propósito da repulsa é não se deparar com o que se evita ${ }^{24}$. Quem falha no desejo é não-afortunado. Quem se depara com o que evita é desafortunado. Caso, entre as coisas que são teus encargos, somente rejeites as contrárias à natureza ${ }^{25}$, não te depararás com nenhuma coisa que evitas. Caso rejeites a doença, a morte ou a pobreza, serás desafortunado. [2.2] Então retira a repulsa de todas as coisas que não sejam encargos nossos e transfere-a para as coisas que, sendo encargos nossos, são contrárias à natureza. Por ora, suspende por completo o desejo, pois se desejares alguma das coisas que não sejam encargos nossos, necessariamente

de Epicteto V.1.5) observa que tal representação é chamada tracheia (dura, bruta) por ser contrária à razão, tornando 'áspera' a vida. Oldfather (1928) e White (1983) traduzem esse adjetivo por 'harsh'; Gourinat (1998), por 'pénible'; García (1995), por 'bruta'. Cf. Diatribes I.27; II.18.24; III.12.15; III.24.108; Aulo Gélio, XIX, 1; Cícero, De Finibus, V, 26.

${ }^{21}$ Phainomenon, particípio presente médio do verbo phaino. Cf. Diatribes II.18.24; III.12.15; Simplício, Comentário ao Encheiridion de Epicteto V.1.5.

${ }^{22}$ Cf. Diatribes II.24.106.

${ }^{23}$ Epangelia: substantivo relacionado ao verbo epangello, que significa primariamente 'anunciar, declarar, proclamar', adquirindo também os sentidos de 'ordenar, comandar, prometer'. A opção por 'propósito' dá-se em razão do significado de 'finalidade' registrado no dicionário Aurélio. Cf. Diatribes III.23.9; I.4.1; II.2; III.2; III.2.8; III.2.13; III.13.21; IV.4. 18; Encheiridion 48.3; Marco Aurélio, IX.7; XI.37.

${ }^{24}$ Trabalha-se aqui com a oposição entre orexis (desejo) e ekklisis (repulsa).

${ }^{25}$ No âmbito da presente tradução, 'natureza' é nosso vocábulo para verter physis. 
não serás afortunado. Das coisas que são encargos nossos, todas quantas seria belo desejar, nenhuma está ao teu alcance ainda. Assim, faz uso somente do impulso e do refreamento ${ }^{26}$, sem excesso, com reserva ${ }^{27}$ e sem constrangimento.

[3] Sobre cada uma das coisas que seduzem ${ }^{28}$, tanto as que se prestam ao uso quanto as que são amadas ${ }^{29}$, lembra de dizer de que qualidade ela é, começando a partir das menores coisas. Caso ames um vaso de argila, <diz> que "Eu amo um vaso de argila", pois se ele se quebrar, não te inquietarás. Quando beijares ternamente teu filho ou tua mulher, <diz> que beijas um ser humano, pois se morrerem, não te inquietarás.

[4] Quando estiveres prestes a empreender alguma ação, recorda-te de que qualidade ela é. Se fores aos banhos, considera o que acontece na sala de banho: pessoas que espirram água, empurram, insultam, roubam. Empreenderás a açáo com mais segurança se assim disseres prontamente: "Quero banhar-me e manter a minha escolha ${ }^{30}$ segundo a natureza". E do mesmo

${ }^{26}$ Aphorme designa o 'ponto de partida', adquirindo os sentidos de 'origem de algo', 'pretexto para fazer algo', significando também 'base para operaçóes militares'. Entre os estoicos, o termo é empregado para designar o princípio contrário de horme.

27 'Com reserva' traduz meth'hypexaireseos (em latim: cum exceptione). Cf. Sêneca, Dos Beneficios, IV, 34: "Non mutat sapiens consilium [...] ad omnia cum exceptione venit"; Da Tranquilidade da Alma, 13; Marco Aurélio, IV.1; V.20; VI.50; XI.37. A meth'hypexaireseos se opóem as expressóes to ex hapantos e ek pantos tropon.

${ }^{28}$ Psychagogeo significa literalmente 'conduzir ou evocar a psyche', adquirindo os sentidos de 'encantar, seduzir, alegrar'. Cf. Diatribes III.24.84 ss.

29 Stergo: amor fraternal expresso entre pais, filhos e cônjuges. É empregado também em relação a animais de estimação e a valores morais, como o amor pela justiça.

${ }^{30}$ Prohairesis: segundo Bailly (2000), o termo expressa a 'escolha 
modo para cada ação. Pois se houver algum entrave ${ }^{31}$ ao banho, terás à mão que "Eu não queria unicamente banhar-me, mas também manter minha escolha segundo a natureza - e não a manterei se me irritar com os acontecimentos" 32 .

[5a] As coisas não inquietam os homens, mas as opinióes sobre as coisas $^{33}$. Por exemplo: a morte nada tem de terrível ${ }^{34}$, ou também a Sócrates teria se afigurado assim, mas é a opinião a respeito da morte - de que ela é terrível - que é terrível. Então, quando se nos apresentarem entraves, ou nos inquietarmos, ou nos afligirmos, jamais consideremos outra coisa a causa, senão nós mesmos - isto é: as nossas próprias opiniōes.

[5b] É ação de quem não se educou ${ }^{35}$ acusar os outros pelas coisas que ele próprio faz erroneamente. De quem começou a se educar ${ }^{36}$, acusar a si próprio. De quem já se educou, não acusar os outros nem a si próprio.

antecipada, a tomada de partido ou o desejo premeditado', adquirindo os sentidos de 'vontade, plano e intençáo'. Marcando oposição com ananke (necessidade), em alguns contextos é vertido por 'livre-arbítrio'. O termo é traduzido como 'moral purpose' por Oldfather (1928); 'choice' por White (1983); 'choix’ por Gourinat (1998); e ‘albedrío’ por García (1995).

31 Literalmente: 'caso haja algo de maneira a entravar o banho'. A expressáo 'de maneira a entravar o banho' seria uma possibilidade de traduçáo praticamente literal para o advérbio empodon, relacionado ao verbo empodizo ('meter os pés em uma armadilha'), que aqui vertemos por 'entravar-se'. No capítulo 1, 'entravar-se' refere-se a dar vazão a desejos cuja satisfação não dependa de nós, levando-nos a afliçóes e sofrimentos. Neste capítulo, o termo relaciona-se a aborrecer-se e deixar-se desviar por acontecimentos que náo antecipamos.

${ }^{32}$ Cf. Diatribes II.17.27

${ }_{33}$ Cf. Diatribes II.16.22-40; III.26-38; I.19.7; I.25.28; IV.1.59, IV.1.85.

${ }^{34}$ Cf. Diatribes II.10 ss.; III.26.38.

${ }^{35}$ Cf. Diatribes III.19 (início) e III.5.4.

${ }^{36}$ Cf. Diatribes II.11 (início). 
[6] Não te exaltes por nenhuma vantagem de outrem. Se um cavalo dissesse, exaltando-se: "Sou belo", isso seria tolerável. Mas quando tu, exaltando-te, disseres: "Possuo um belo cavalo", sabe que te exaltas pelo bem do cavalo ${ }^{37}$. Então o que é teu? O uso das representaçóes ${ }^{38}$. Desse modo, quando utilizares as representaçóes segundo a natureza, aí então te exalta, pois nesse momento te exaltarás por um bem que depende de ti.

[7] Em uma viagem marítima, se saíres para fazer provisão de água quando o navio estiver ancorado, poderás também pegar uma conchinha e um peixinho pelo caminho ${ }^{39}$. Mas é preciso que mantenhas o pensamento fixo sobre o navio, voltando-te continuamente. Que jamais o piloto te chame. E se te chamar, abandona tudo para que não sejas lançado ao navio amarrado como as ovelhas. Assim também é na vida. Não será um obstáculo se ela te der, ao invés de uma conchinha e um peixinho, uma mulherzinha e um filhinho ${ }^{40}$. Mas se o capitão te chamar, corre para o navio, abandonando tudo, sem te voltares para trás. E se fores velho, nunca te afastes muito do navio, para que, um dia, quando o piloto te chamar, não fiques para trás.

${ }^{37}$ Cf. Diatribes II.24.11.

${ }^{38}$ Cf. Diatribes I.1.7.

${ }^{39}$ A utilização do vocábulo 'peixinho' para traduzir bolbarion baseia-se no comentário de Pierre Hadot e Ilsetraut Hadot no artigo La Parabole de L'escale (2004). Como observam os Hadot, embora bolbarion usualmente signifique o diminutivo de cebola (bolbos), no grego tardio pode designar também uma espécie de cefalópode (Cf. Lamp, 1961, artigo bolbos). Neste capítulo, segundo os Hadot, 'as duas palavras (kolchlidion e bolbarion) se referem às conchas espiraladas ou aos animais que se encontram nas praias'.

${ }^{40}$ Cf. Diatribes III.24.34. 
[8] Não busques que os acontecimentos aconteçam como queres, mas quere que aconteçam como acontecem, e tua vida terá um curso sereno ${ }^{41}$.

[9] A doença é entrave para o corpo $^{42}$, mas não para a escolha ${ }^{43}$, se ela não quiser. Claudicar é entrave para as pernas, mas não para a escolha. Diz isso para cada uma das coisas que sucedem contigo, e descobrirás que o entrave é próprio de outra coisa e náo teu.

[10] Quanto a cada uma das coisas que sucedem contigo, lembra, voltando a atenção para ti mesmo, de buscar alguma capacidade que sirva para cada uma delas ${ }^{44}$. Caso vires um belo homem ou uma bela mulher, descobrirás para isso a capacidade do autodomínio. Caso uma tarefa extenuante se apresente, descobrirás a perseverança ${ }^{45}$. Caso a injúria, a paciência. Habituando-te desse modo, as representaçóes não te arrebatarão ${ }^{46}$.

${ }^{41}$ Euroeo: verbo relacionado ao adjetivo euroos, que, em um de seus significados mais concretos, qualifica um fluxo de água - o jorro de uma fonte ou a correnteza de um rio - que flui facilmente. Essa ideia de um fluxo de água que corre sem encontrar obstáculos é empregada por Epicteto para qualificar uma condição de vida tranquila, próspera, sem entraves que motivem agitação e sofrimento. A frase grega que vertemos por 'a tua vida terá um curso sereno' é traduzida como 'your life will be serene' por Oldfather (1928); 'your life will go well' por White (1983); 'ta vie suivra um cours heureux' por Gourinat (1998); e 'viverás sereno’ por García (1995). Cf. Diatribes I.12.15 ss.; II.14.7; IV.7.20.

${ }^{42}$ Do mesmo modo em Sêneca, Cartas a Lucilio, LXXXVIII (Corpus tuum valetudo tenet, non animum [...]).

${ }^{43}$ Cf. Diatribes I.1.23; I.17.21 e 26; I.18.11; I.22.10; I.29.10; II.5.4; III.22.105; IV.13.7.

${ }^{44}$ Cf. Diatribes I.6.28; I.12.30 ss.; II.16.14; IV.1.109.

${ }_{45}$ Karteria: substantivo feminino relacionado ao verbo kartereo (que significa "ser firme, forte', adquirindo o sentido de 'ser obstinado' e 'ser paciente') e ao adjetivo karteroos ('forte, firme, sólido'). A adoção de 'perseverança' liga-se à sua relaçáo com a ideia de manter-se firme em um comportamento, mesmo que diante de dificuldades.

${ }^{46}$ Cf. Diatribes II.18.24 e 28; II.23.33; Marco Aurélio, V.36. 
[11] Jamais, a respeito de coisa alguma, digas: "Eu a perdi", mas sim: "Eu a restituí". O filho morreu? Foi restituído. A mulher morreu? Foi restituída ${ }^{47}$. "A propriedade me foi subtraída", então também foi restituída! "Mas quem a subtraiu é mau!" O que te importa por meio de quem aquele que te dá a pede de volta? Na medida em que ele der, faz uso do mesmo modo de quem cuida das coisas de outrem. Do mesmo modo dos que se instalam em uma hospedaria ${ }^{48}$.

\section{[12.1] Se queres progredir ${ }^{49}$, abandona pensamentos} como estes: "Se eu descuidar dos meus negócios, não terei o que comer", "Se eu não punir o servo, ele se tornará inútil". Pois é melhor morrer de fome, sem aflição e sem medo, que viver inquieto na opulência. É melhor ser mau o servo que tu infeliz ${ }^{50}$. [12.2] Começa a partir das menores coisas $^{51}$. Derrama-se um pouco de azeite? É roubado um pouco de vinho? Diz: "Por esse preço é vendida a ausência de sofrimento"; "Esse é o preço da tranquilidade". Nada vem de graça ${ }^{52}$. Quando chamares o servo, pondera que é possível que ele náo venha, ou, se vier, que ele não faça o que queres. Mas a posição dele não é tâo boa para que dele dependa a tua tranquilidade ${ }^{53}$.

${ }^{47}$ Cf. Diatribes I.1.32.

${ }^{48}$ Cf. Diatribes II.23.36.

${ }^{49}$ Prokopto significa literalmente 'estirar ou alongar uma placa de metal a golpes de martelo', adquirindo o sentido figurativo de 'progredir', 'avançar em direção a algo'.

${ }^{50}$ Segundo Schweighäuser (1799, (vol 3), p.xx), Epicteto observa que, ao se castigar alguém em razão da ira ou do desejo de corrigi-lo, o que castiga se encontra desde já no erro por querer controlar algo que náo depende de si, resultando daí a perda da tranquilidade. Cf. Encheiridion 14 e 15.

${ }^{51}$ Cf. Diatribes I.18.18; IV.1.111.

${ }^{52}$ Cf. Diatribes IV.2.2; IV.10.19.

${ }^{53}$ Cf. Marco Aurélio, VIII.45; VIII.56. 
[13] Se queres progredir, conforma-te em parecer insensato e tolo quanto às coisas exteriores. Não pretendas parecer saber coisa alguma. E caso pareceres ser alguém <importante> para alguns, desconfia de ti mesmo, pois sabe que não é fácil guardar a tua escolha, mantendo-a segundo a natureza, e, <ao mesmo tempo>, as coisas exteriores, mas necessariamente quem cuida de uma descuida da outra.

[14a] Se quiseres que teus filhos, tua mulher e teus amigos vivam para sempre, és tolo, pois queres que as coisas que não são teus encargos sejam encargos teus, como também que as coisas de outrem sejam tuas ${ }^{54}$. Do mesmo modo, se quiseres que o servo não cometa faltas, és insensato, pois queres que o vício não seja o vício, mas outra coisa. Mas se quiseres náo falhar em teus desejos, isso tu podes. Então exercita o que tu podes.

[14b] O senhor de cada um é quem possui o poder de conservar ou afastar as coisas desejadas ou não desejadas por cada um. Entáo, quem quer que deseje ser livre, nem queira, nem evite o que dependa de outros. Senão, necessariamente será escravo.

[15] Lembra que é preciso que te comportes como em um banquete ${ }^{55}$. Uma iguaria que está sendo servida chega a ti? Estendendo a mão, toma a tua parte disciplinadamente ${ }^{56}$. Passa

${ }^{54}$ Cf. Diatribes IV.5.7.

${ }^{55}$ Cf. Diatribes II.16.37 e Encheiridion 36.

56 'Disciplinadamente' é nossa tradução para o advérbio kosmios. Bailly (2000) registra os significados de 'com ordem' e 'com medida'. Oldfather (1928) e White (1983) o traduzem por 'politely'; Gourinat (1998), por 
ao largo? Não a persigas. Ainda não chegou? Não projetes o desejo, mas espera até que venha a ti. $<$ Age $>$ do mesmo modo em relação aos teus filhos, à tua mulher, aos cargos, à riqueza, e um dia serás um valoroso conviva dos deuses. Porém, se não tomares as coisas mesmo quando sejam colocadas diante de ti, mas as desdenhares, nesse momento não somente serás um conviva dos deuses, mas governarás com eles. <Agindo $>$ dessa maneira, Diógenes, Heráclito e seus semelhantes foram, por mérito, divinos, e assim foram chamados.

[16] Quando vires alguém aflito, chorando pela ausência do filho ou pela perda de suas coisas, toma cuidado para que a representação de que ele esteja envolto em males externos não te arrebate, mas tem prontamente à mão que não é o acontecimento que o oprime (pois este não oprime outro), mas sim a opinião sobre $<0$ acontecimento $>$. No entanto, não hesites em solidarizar-te com ele com tuas palavras e, caso caiba, em lamentar-te junto ${ }^{57}$. Mas toma cuidado para também não gemeres por dentro ${ }^{58}$.

[17] Lembra que és um ator de uma peça teatral ${ }^{59}$, tal como o quer o autor <da peça>. Se ele a quiser breve, breve será. Se ele a quiser longa, longa será. Se ele quiser que interpretes o papel de mendigo, é para que interpretes esse papel com talento. $<\mathrm{E}$, da mesma forma, $>$ se $<$ ele quiser que interpretes o papel $>$ de coxo, de magistrado, de homem

\footnotetext{
'convenablement'; e García (1995), por 'moderadamente'.

${ }^{57}$ Cf. Diatribes I.9.12; I.29.64; III.14.7; III.16.4; IV.2 ; IV.12.17.

${ }^{58}$ Cf. Diatribes I.18.19; Cícero, Tusc. Disp. II.22; Aulo Gélio, XVII.

${ }^{59}$ Cf. Diatribes I.29.42 ss.; IV.2.9; IV.7.13; Marco Aurélio, XI.6; XII.36; Estobeu, Sermo cvi ex telete, de casibus e 68 i; Sermo I e V; Diógenes Laércio VII 160; Sêneca, Cartas a Lucílio, LXXVII ('quomodo fabula, sic vita [...]'); Cícero, De Officiis, I,28 e 31; Procópio de Gaza, Cartas XIV.
} 
comum $^{60}$. Pois isto é teu: interpretar belamente o papel que te é dado - mas escolhê-lo, cabe a outro.

[18] Quando um corvo crocitar maus auspícios, que a representação não te arrebate, mas prontamente efetua a distinção ${ }^{61}$ e diz: "Isso nada significa para mim, mas ou ao meu pequenino corpo, ou às minhas pequeninas coisas, ou à minha reputaçãozinha, ou aos meus filhos, ou à minha mulher. Se eu quiser, todas as coisas significam bons auspícios para mim - pois se alguma dessas coisas ocorrer, beneficiar-me delas depende de mim" ${ }^{\prime 2}$.

[19a] Podes ser invencível se não te engajares em lutas nas quais vencer não depende de ti ${ }^{63}$.

[19b] Ao vires alguém preferido em honras, ou muito poderoso, ou mais estimado, presta atenção para que jamais creias - arrebatado pela representação - que ele seja feliz ${ }^{64}$.

${ }^{60}$ Neste capítulo, Epicteto faz referência à teoria dos papéis de Panécio de Rhodes (apresentada por Cícero no De Officiis, I, xxx, 107xxxiii, 121), tendo em mente o papel que é determinado ao homem pela divindade. Assim, na presente passagem, idiotes ('homem comum' em nossa tradução) se refere ao simples cidadão, que não é de estirpe patrícia e não tem o direito de ocupar cargos eletivos nas cidades do Império Romano. Em outras passagens, Epicteto opóe idiotes (que deve ser compreendido, então, por 'homem sem instruçáo') ao filósofo (Cf. Encheiridion 48).

${ }^{61}$ 'Efetua a distinção' refere-se ao exercício da regra, apresentada ao final do capítulo 1, que o discípulo deve usar diante de uma representação bruta. Em primeiro lugar, é preciso perceber que o que incomoda não é a própria coisa que está se manifestando, mas sim a representação (e, consequentemente, o juízo) que se faz dela. Em segundo lugar, é preciso determinar se a representação se refere a coisas que são encargos nossos ou náo. Caso se refira a coisas que não são encargos nossos, deve-se dizer prontamente: 'Nada é para mim'.

${ }^{62}$ Cf. Diatribes III.20.

${ }^{63}$ Cf. Diatribes III.6.5; III.22.102.

${ }^{64}$ Trata-se do verbo makarizo, tradicionalmente vertido por 'ser feliz'. É 
Pois se a essência do bem ${ }^{65}$ está nas coisas que são encargos nossos, não haverá espaço nem para a inveja, nem para o ciúme. Tu mesmo não irás querer ser nem general, nem prítane ou cônsul, mas homem livre. E o único caminho para isso é desprezar o que não é encargo nosso.

[20] Lembra que não é insolente quem ofende ou agride, mas sim a opiniáo segundo a qual ele é insolente. Então, quando alguém te provocar, sabe que é o teu juízo que te provocou. Portanto, em primeiro lugar, tenta náo ser arrebatado pela representação: uma vez que ganhares tempo e prazo, mais facilmente serás senhor de ti mesmo.

[21] Que estejam diante dos teus olhos ${ }^{66}$, a cada dia, a morte, o exílio e todas as coisas que se afiguram terríveis, sobretudo a morte. Assim, jamais ponderarás coisas abjetas, nem aspirarás à ${ }^{67}$ coisa alguma excessivamente.

[22] Se aspiras à filosofia, prepara-te, a partir de agora, para quando te ridicularizarem, para quando rirem de ti, para quando indagarem: "Subitamente ele nos volta filósofo?"

importante ressaltar a ligação desse vocábulo com os aspectos divinos que ele encerra. Chantraine (1984) registra para o adjetivo makar o significado de 'bem-aventurado', normalmente empregado no plural, referindo-se aos deuses (os bem-aventurados). Em Homero, o adjetivo aparece também associado aos homens, qualificando a condição de alguém favorecido pelos deuses (Cf. Ilíada, 3, 182). Uma proposta de tradução literal, buscando uma estreita relação com a condição divina da felicidade, poderia ser: 'Que ele seja bem-aventurado'.

${ }^{65}$ Cf. Diatribes I.20.15; I.29.1 e 18; II.1. 4; II.8. 9; II. 20. 9; IV.13.14 ss.; III.7.6.

${ }^{66}$ Cf. Diatribes III.24.104 ss.; III.10.6.

67 Epithymeo: Oldfather (1928) traduz o termo por 'yearn'; White (1983), por 'crave'; Gourinat (1998), por 'aspire'; García (1995), por 'ansías'. Optamos por 'aspirar', pois o vocábulo se remete à ideia de colocar algo dentro ou em cima do peito. 
e "De onde vem essa gravidade no olhar? ${ }^{38 " ~ N a ̃ o ~ a d q u i r a s ~}$ tal gravidade no olhar, mas, como quem é designado a esse posto $^{69}$ pela divindade, agarra-te às coisas que se afiguram as melhores para $\mathrm{ti}^{70}$. Lembra que, se te prenderes a essas mesmas coisas, os que primeiro rirem de ti depois te admirarão. Mas se te deixares vencer por eles, receberás as risadas em dobro.

[23] Se alguma vez te voltares para as coisas exteriores por desejares agradar alguém, sabe que perdeste o rumo ${ }^{71}$. Basta que sejas filósofo em todas as circunstâncias ${ }^{72}$. Mas se desejares também parecer < filósofo $>$, exibe-te para ti mesmo - será o suficiente ${ }^{73}$.

[24.1] Que estes raciocínios não te oprimam: "Viverei sem ser honrado e ninguém serei em parte alguma”. Pois se a falta de honra ${ }^{74}$ é um mal - como o é -,

${ }^{68}$ Literalmente: "De onde vem esta sobrancelha?". Bailly (2000) registra os sentidos figurativos de 'gravidade' e 'majestade' para ophrys (sobrancelha). Hadot (2000, p. 176-7, nota 1) observa que essa referência à afetação e à arrogância de filósofos lembra a descrição que Aristófanes faz de Sócrates em As Nuvens (363).

${ }^{69}$ Cf. Diatribes I.9.16; III.1.19; Platão, Apologia 28 e.

${ }^{70}$ Cf. Diatribes II.6.9; II.10.6; Encheiridion 51.2; Platão, Crítias, c6.

${ }^{71}$ Cf. Diatribes III.1.2-5.

${ }^{72}$ Como Sócrates. Cf. Diatribes IV.8.23.

${ }^{73}$ Cf. Encheiridion 14.1.

${ }^{74} \operatorname{Boter}(1999$, p. 124) observa que, se entendermos atimia simplesmente como 'falta de honras', o texto perde o sentido, já que tal falta de honras é para os estoicos um indiferente. Assim, é preciso distinguir entre a real e a aparente atimia, sendo aquela um mal verdadeiro na medida em que é compreendida como falta de valor e esta um mal aparente na medida em que é compreendida como o mero fato de náo ser valorizado pelos outros. A identificação de time com excelência moral e atimia com o seu contrário é doutrina estoica genuína (Cf. SVF III 563; SVF III 312). Boter (1999, p. 125) assim interpreta o que Epicteto quer dizer na passagem em questão: 'Temes a atimia? Estás certo, porque ela é má e vergonhosa; entretanto, a atimia não é o que pensas; ela não depende do que os outros fazem ou pensam sobre ti, mas apenas de ti mesmo' (Cf. Encheiridion 40). 
não se pode ficar em mau estado por causa de outro, não mais do que em situação vergonhosa ${ }^{75}$. É ação tua obter um cargo público ou ser convidado para um banquete? De modo algum. Como então <não obter um cargo ou não ser convidado para um banquetes é ser desonrado? Como também não serás ninguém se é preciso que sejas alguém unicamente em relaçâoo às coisas sob teu encargo, coisas nas quais podes ser do mais alto valor? [24.2] Mas teus amigos ficarão desamparados? Desamparados! Dizes isso em relação a que? Não terão de ti uns trocados, nem os farás cidadãos de Roma? Quem te disse que essas coisas estâo sob teu encargo e nâo são ações de outrem? Quem é capaz de dar a outro o que ele mesmo não possui? "Obtém posses", diz <alguém>, "para que também nós as tenhamos". [24.3] Se eu puder obter posses mantendo-me digno, leal e magnânimo, indicai-me o caminho e eu as obterei. Mas se credes digno que eu perca meus bens - os que me são próprios - para que conserveis coisas que não são bens, atentai como sois iníquos e ignorantes. O que desejais mais: dinheiro ou um amigo leal e digno? Ajudai-me sobretudo nisso e não creiais ter valor que eu faça coisas pelas quais rejeitaria o que é propriamente meu. [24.4] "Mas a pátria", diz <alguém>, "no que depender de mim, estará desamparada". Pelo contrário, pois de que tipo seria esse amparo? <A pátria> não terá por teu intermédio pórticos nem banhos públicos? E daî́? Pois não há sandálias por intermédio do ferreiro nem armas por intermédio do sapateiro, mas basta que cada um cumpra a ação que lhe é própria. Se forneceres <para a pátria> outro cidadão leal e digno em nada a beneficiarias? Sim. Então tu mesmo não serias inútil à pátria. [24.5] "Que lugar", diz <alguém>, "terei na cidade?" O que te for

\footnotetext{
${ }^{75}$ Cf. Diatribes I.9.34; I.28.23; Sêneca, Cartas a Lucílio, LXX.
} 
possível, mantendo-te, ao mesmo tempo, leal e digno. Mas se, desejando beneficiar a cidade, rejeitares essas qualidades, que benefício serias para $<$ a cidade $>$ tornando-te indigno e desleal?

[25.1] Se alguém receber maiores honras do que tu em um banquete, em uma saudação ou ao ser acolhido no conse$\mathrm{lho}^{76}$, e se essas coisas forem um bem, é preciso alegrar-te por ele as ter obtido. Mas se forem males, não sofras porque não as obtiveste. Lembra que não podes - se não agires para obter coisas que não são encargos nossos - merecer uma parte igual <à dos que agem para obtê-las>. [25.2] Pois como quem náo vai periodicamente à porta de alguém pode obter o mesmo que quem vai? Quem acompanha, o mesmo que quem não acompanha? Quem elogia, o mesmo que quem não elogia? Serias injusto e insaciável se, não pagando o preço pelo qual aquelas coisas são vendidas, desejasses obtê-las gratuitamente. [25.3] Por quanto é vendida uma alface? Que custe um óbolo! Então quem dispensa o óbolo toma a alface, e tu, que não o dispensaste, não a tomas. Não penses ter menos do que quem a tomou, pois, do mesmo modo que ele possui a alface, tu possuis o óbolo que não entregaste ${ }^{77}$. [25.4] Assim também é neste caso: náo foste convidado para o banquete de alguém, pois não deste ao anfitrião a quantia pela qual ele vende a refeição. Ele a vende por elogios, por obséquios. Se te é vantajoso, paga o preço pelo qual ela é vendida. Mas se queres não pagar por ela e obtê-la, és insaciável e estúpido. [25.5] Então nada tens no lugar do repasto? Com certeza!

${ }^{76}$ Cf. Diatribes III.24.44 ss.

${ }^{77}$ Cf. Diatribes I.19.21; Encheiridion 31.13; Sêneca, Da Constância do Sábio, 14; Luciano, Nigrinus 21. Um óbolo corresponde à sexta parte de uma dracma. 
Não terás que elogiar quem não queres, nem aturar os que estáo diante da porta dele.

[26] Aprende-se o propósito da natureza a partir do que não discordamos uns dos outros. Por exemplo: quando o servo de outrem quebra um copo, tem-se prontamente à mão que "Isso acontece". Entáo se o teu copo se quebrar, sabe que é preciso que ajas tal como quando o copo de outro se quebra. Do mesmo modo, transfere isso também para as coisas mais importantes. Morre o filho ou a mulher de outro? Não há quem não diga: "É humano". Mas quando morre o próprio < filho ou a própria mulher>, diz-se prontamente: "Ó desafortunado que sou!"78 É preciso que lembremos como nos sentimos quando ouvimos a mesma coisa acerca dos outros.

[27] Do mesmo modo que um alvo não é fixado para não ser atingido, assim também a natureza do mal não existe no $\operatorname{cosmos}^{79}$.

[28] Se alguém entregasse teu corpo a quem chegasse, tu te irritarias. E por que entregas teu pensamento ${ }^{80}$ a quem quer que apareça, para que, se ele te insultar, teu pensamento se inquiete e se confunda? Náo te envergonhas por isso?

[29.1] A respeito de cada ação, examina o que a antecede e o que a sucede e entáo a empreende. Senão, primeiro te entusiasmarás e, por náo teres ponderado

${ }^{78}$ Cf. Diatribes I.4.23 .

${ }^{79}$ A mesma imagem aparece em Cícero no De Finibus III, 22.

${ }^{80}$ Gnome. 
sobre as consequências, depois, quando estas se mostrarem vergonhosas, desistirás. [29.2] Queres vencer os Jogos Olímpicos? Também eu, pelos deuses, pois é uma coisa bela. Mas examina o que antecede e o que segue <tal vitória $>$ e então empreende a ação. É preciso ser disciplinado, submeterse a regime alimentar, abster-se de guloseimas, exercitar-se obrigatoriamente na hora determinada (tanto no calor como no frio), não beber água gelada nem vinho, mesmo que ocasionalmente. Em suma, <é preciso> confiar-se ao treinador como ao médico. Depois, <é preciso> lançar-se à luta e, por vezes, machucar as mãos, torcer o tornozelo e engolir muita areia. Às vezes, tanto ser fustigado quanto, depois de tudo isso, ser vencido. [29.3] Tendo examinado essas coisas, caso ainda queiras, torna-te atleta. Senão, do mesmo modo que as crianças se comportam (ora elas brincam de lutador, ora de gladiador, ora tocam trombetas, depois encenam uma tragédia), também tu serás ora atleta, ora gladiador, depois orador, em seguida filósofo, mas nada <serás $>$ com tua alma toda. Como um macaco, imitarás tudo o que vires. Uma coisa após a outra te agradará, pois nada empreenderás após exame e investigação, mas <agirás> ao acaso e sem ardor. [29.4] Alguns, ao contemplarem e ouvirem um filósofo (um desses que falam bem como Sócrates - e, de fato, quem é capaz de falar como ele?), querem também eles próprios ser filósofos. [29.5] Homem! Examina primeiro de que qualidade é a coisa, depois observa a tua própria natureza para saber se a podes suportar. Desejas ser pentatleta ou lutador? Olha teus braços e coxas. Observa teus flancos, [29.6] pois cada um nasceu para uma coisa. Crês que, <sendo filósofo $>,{ }^{81}$ podes comer do mesmo modo, beber do mesmo modo, ter regras e falta de humor semelhantes? É preciso que faças vigílias,

${ }^{81}$ Literalmente: 'fazendo essas coisas'. 
que suportes fadigas, que te afastes da tua família, que sejas desprezado pelos servos, que todos riam de ti, que tenhas a menor parte em tudo: nas honras, nos cargos públicos, nos tribunais, em todo tipo de assunto de pequena monta. [29.7] Examina essas coisas se queres receber em troca delas a ausência de sofrimento, a liberdade e a tranquilidade. Caso contrário, não te envolvas. Não sejas, como as crianças, agora filósofo, depois cobrador de impostos, em seguida orador, depois procurador de César. Essas coisas não combinam. É preciso que sejas um homem, bom ou mal. É preciso que cultives a tua própria faculdade diretriz ou as coisas exteriores. É preciso que assumas ou a arte acerca das coisas interiores ou acerca das exteriores. Isto é: que assumas ou o posto de filósofo ou o de homem comum ${ }^{82}$.

[30] As ações convenientes são, em geral, medidas pelas relaçóes ${ }^{83}$. É teu pai? Isso implica que cuides dele, que cedas em tudo, que o toleres quando te insulta, quando te bate. Mas ele é um mau pai? De modo algum, pela natureza, estás unido a um bom pai, mas a um pai. “<Meu> irmão é injusto". Mantém o teu próprio posto em relação a ele. Não examines o que ele faz, mas o que te é dado fazer, e a tua escolha estará segundo a natureza. Pois se não quiseres, outro não te causará dano, mas sofrerás dano quando supuseres ter sofrido dano. Deste

${ }^{82}$ Cf. Diatribes III.15. Esse capítulo todo é uma interpolação, pois é omitido por boa parte da tradição, incluindo Simplício. Além disso, trata-se de longa passagem das Diatribes (III.15.1-13) reproduzida no Encheiridion quase ipsis litteris. Tal fato não se repete no Encheiridion, visto Arriano sempre reescrever os textos ao transladá-los das Diatribes para o Encheiridion. Entretanto, Hadot (2000, p. 203) considera que o interpolador colocou tal capítulo em bom lugar, visto encontrar-se no princípio da parte que se relaciona à 'disciplina da ação'.

${ }^{83}$ Cf. Diatribes II.10; IV.4.16; IV.6.26; IV.10.15; IV.12.16. 
modo então descobrirás as açôes convenientes para com o vizinho, para com o cidadão, para com o general: se te habituares a considerar as relaçóes.

[31.1] ${ }^{84}$ Quanto à piedade em relação aos deuses, sabe que o mais importante é o seguinte: que possuas juízos corretos sobre eles (que eles existem e governam todas as coisas de modo belo e justo) e que te disponhas a obedecê-los e a aceitar todos os acontecimentos, seguindo-os voluntariamente como realizaçóes da mais elevada inteligência. Assim, não censurarás jamais os deuses, nem os acusarás de terem te esquecido. [31.2] Mas isso só é possível se tirares o bem e o mal das coisas que não são encargos nossos e os colocares nas únicas coisas que são encargos nossos. Pois se supuseres boas ou más algumas das coisas que não são encargos nossos, é absolutamente necessário - quando não atingires as que queres, ou te deparares com as que náo queres - que censures e odeies os responsáveis. [31.3] Pois é natural a todo vivente evitar e afastar-se das coisas que se afiguram nocivas e de suas causas, como também buscar e admirar as coisas benéficas e suas causas ${ }^{85}$. Então é inconcebível que alguém, pensando sofrer algum dano, alegre-se com o que lhe parece danoso. Do mesmo modo, também, é impossível que se alegre com o próprio dano. [31.4] Daí também isto: um pai é ofendido pelo filho quando não partilha com este as coisas que a este parecem boas. Polinices e Eteocles também agiram assim, por acreditarem que a tirania fosse um bem ${ }^{86}$.

${ }^{84}$ Quanto ao sentido do capítulo como um todo, cf. Diatribes I.10; II.14.11 ss.; III.24.113; III.26.28.

${ }^{85}$ Cf. Diatribes I.22,14; I.27.12; III.22.15 e 19; III.3.2

${ }^{86}$ Polinices e Eteocles sáo filhos de Édipo que se envolveram em um conflito mortal pela obtençáo do poder em Tebas. Essa trama é utilizada 
Em razão disso, o camponês insulta os deuses, bem como o marinheiro, o comerciante, os que perdem as mulheres e os filhos ${ }^{87}$. Pois aí onde está o interesse, aí também está a piedade ${ }^{88}$. Quem cuida do desejo e da repulsa como se deve cuida também, do mesmo modo, da piedade. [31.5] Convém fazer libaçôes, sacrifícios e oferecer primícias ${ }^{89}$, segundo os costumes ancestrais de cada um, mas de modo puro, não de modo indolente, nem descuidado ${ }^{90}$, nem mesquinho, nem acima da própria capacidade ${ }^{91}$.

[32.1] Quando recorreres à divinação, lembra que não sabes o que está por vir, mas vais ao adivinho para seres informado sobre isso. Vais sabendo, já que és filósofo, qual é a qualidade do que está por vir: se for algo que não seja encargo nosso, é absolutamente necessário que não seja nem um bem, nem um mal. [32.2] Então não leves ao adivinho desejo ou repulsa, senão te apresentarás tremendo diante dele. Mas, discernindo que tudo o que vier é indiferente, e nada (seja o que for) se refere a ti, pois poderás fazer bom uso < do acontecimento> (e isso ninguém te impedirá), vai, confiante, aos deuses, <vendo-os $>$ como $<$ teus $>$ conselheiros. Além disso, quando algo te for aconselhado, lembra quais conselheiros tu acolhes e quais, desobedecendo, recusarás ouvir. [32.3] Consulta o oráculo do mesmo modo que Sócrates julgava ter valor: para os casos nos quais o exame

como pano de fundo na tragédia Antígona, de Sófocles. Cf. Diatribes II.22.13 ss.; IV.5.29; Xenofonte, Memoráveis, I.1.7.

${ }^{87}$ Cf. Diatribes I.27.13 ss.; II.22.17; III.4.6.

${ }^{88}$ Cf. Diatribes I.9.25; I.27.14.

${ }^{89}$ Hadot (2000, p. 185, nota 1) observa que os antigos, durante oraçóes ou cultos aos mortos, faziam oferendas de vinho, mel e leite (Cf. Porfírio, Da Abstinência II, 20-21).

${ }^{90}$ Cf. Xenofonte, Memoráveis, IV.3.16.

${ }^{91}$ Cf. Xenofonte, Memoráveis, I.3.3; IV.3.10; Diatribes I.12.7; II.5.2. 
como um todo se refere às consequências, e os pontos de partida para conhecer o assunto não são dados nem pela razão, nem por alguma outra arte. Assim, quando precisares compartilhar um perigo com o amigo ou com a pátria, não consultes o oráculo se deves compartilhar o perigo. Pois se o adivinho anunciar maus presságios, é evidente que isso significa ou a morte, ou a perda de alguma parte do corpo, ou o exílio. Mas a razão te impele ${ }^{92}$, mesmo nessas situaçóes, a ficar ao lado do amigo ou da pátria e expor-te ao perigo. Portanto, dá atenção ao maior dos adivinhos, Apolo Pítico, que expulsou do templo o homem que não socorreu o amigo que estava sendo assassinado ${ }^{93}$.

[33.1] Fixa, a partir de agora, um caráter e um padrão para ti próprio, que guardarás quando estiveres sozinho, ou quando te encontrares com outros ${ }^{94}$. [33.2] $\mathrm{Na}$ maior parte do tempo, fica em silêncio, ou, com poucas palavras, fala o que é necessário. Raramente, quando a ocasião pedir, fala algo, mas não sobre coisa ordinária: nada sobre lutas de gladiadores, corridas de cavalos, nem sobre atletas, nem sobre comidas ou bebidas - assuntos falados

${ }^{92}$ Cf. Diatribes I.29.28; II.2.20. Hadot (2000, p. 186, nota 1) observa que tal expressão já se encontra em Platáo (República X 607 b) e é retomada pelos estoicos (quanto a isso, ver também Diógenes Láercio, VII, 108).

${ }^{93}$ Segundo Simplício (Comentário ao Manual de Epicteto XXXIX, 86), Epicteto faz aí referência à história acerca de dois amigos que, estando a caminho de Delfos, foram assaltados. Um dos amigos fugiu, abandonando o outro, que acabou sendo assassinado pelos bandidos. Quando o que fugiu chegou a Delfos e foi consultar o oráculo, foi expulso do templo. Simplício assim reproduz as palavras do oráculo dirigidas ao que abandonara seu amigo: 'Tu que, estando presente e próximo ao amigo à beira da morte e, todavia, não o ajudaste, para que vieste aqui? Homem impuro, profano, sai deste templo purificado!' Cf. Aeliano, Hist. III. 44; Galeno Exortação ao estudo das artes médicas, ii.

${ }^{94}$ Cf. Diatribes III.23 (início). 
por toda parte. Sobretudo não fales sobre os homens, recriminando-os, ou elogiando-os, ou comparando-os. [33.3] Então, se fores capaz, conduz a tua conversa e a dos que estâo contigo para o que é conveniente. Porém, se te encontrares isolado em meio a estranhos, guarda silêncio. [33.4] Não rias muito, nem sobre muitas coisas, nem de modo descontrolado. [33.5] Recusa-te a fazer juramentos, se possível por completo. Senão, na medida do possível ${ }^{95}$. [33.6] Póe de lado os banquetes de estranhos e de homens comuns, mas se um dia surgir uma ocasião propícia, mantém-te atento e jamais caias na vulgaridade. Pois sabe que, quando o companheiro for impuro, quem convive com ele necessariamente se torna impuro, mesmo que, por acaso, esteja puro ${ }^{96}$. [33.7] Acolhe as coisas relativas ao corpo na medida da simples necessidade: alimentos, bebidas, vestimenta, serviçais - mas exclui por completo a ostentação ou o luxo. [33.8] Quanto aos prazeres de Afrodite ${ }^{97}$, deves preservar-te ao máximo até o casamento, mas se te engajares neles, é preciso tomá-los conforme o costume. No entanto, não sejas grave nem crítico com os que fazem uso deles, nem anuncies repetidamente que tu próprio não o fazes. [33.9] Se te disserem que alguém, maldosamente, falou coisas terríveis de ti, não te defendas das coisas ditas, mas responde que "Ele desconhece meus outros defeitos, ou não mencionaria somente esses”. [33.10] Não é necessário ir frequentemente aos espetáculos ${ }^{98}$, mas se surgir uma ocasião propícia, não mostres preocupação com nin-

${ }^{95}$ Cf. Epicteto, fragmento 108 (Schenkl).

${ }^{96}$ Cf. Diatribes III.16 (início).

${ }^{97}$ Deusa do panteáo da Grécia Antiga associada ao amor e ao sexo.

${ }^{98}$ Cf. Diatribes III.4. Hadot (2000, p. 188, nota 1) observa que os espetáculos em questão devem incluir as corridas de carruagens, os combates de gladiadores, as tragédias e as comédias. 
guém senão contigo mesmo - isto é: quere que aconteçam somente as coisas que acontecerem e que vença somente o vencedor, pois assim tu não te farás entraves. E abstém-te por completo de gritar, rir de alguém ou comover-te. Uma vez tendo saído do espetáculo, não fales muito sobre o que lá se passou, na medida em que <isso> não leva à tua correção, pois, a partir de tal <ação>, será evidente que admiraste o espetáculo. [33.11] Nem ao acaso, nem prontamente vás às palestras dos outros ${ }^{99}$, mas se fores, guarda <um caráter $>$ ao mesmo tempo reverente, equilibrado e cordial. [33.12] Quando fores te encontrar com alguém - sobretudo algum dentre os que parecem proeminentes - indaga a ti mesmo o que Sócrates ou Zenão fariam em tais circunstâncias ${ }^{100}$, e não te faltarão meios para agir convenientemente. [33.13] Quando fores encontrar alguém do grupo dos muito poderosos, considera <a possibilidade> de que não o acharás em casa, de que serás impedido de entrar, de que as portas se fecharão para ti ${ }^{101}$, de que ele não te dará atenção. E se ainda assim for conveniente ir, vai. Mas suporta os acontecimentos e jamais digas a ti mesmo: "Isso não vale tanto" ${ }^{102}$. Pois orientar-se pelas coisas exteriores é próprio do homem comum. [33.14] Nas conversas, desiste de lembrar, frequente e desmedidamente, as tuas açóes e aventuras perigosas, pois não é prazeroso para os outros ouvir as

99 Eram comuns em Roma eventos com leituras de textos por seus autores como meio de tornar públicos esses escritos (Cf. Plínio o Jovem, Cartas, obra na qual esse costume é mencionado várias vezes). Cf. Diatribes III. 23.

${ }^{100}$ Cf. Diatribes II.18.21 ss.; II.13.4; Longino, De Sublime 14; Marco Aurélio, XI.26; Sêneca, Cartas a Lucílio, XI: 'Aliquid vir bonus nobis elegendus est, ac semper ad oculus habendus, ut sic tamquam illo spectante vivamus, et omnia tanquam illo vidente faciamus'.

${ }^{101}$ Cf. Diatribes II.13.17 ss.

${ }^{102}$ Cf. Diatribes II.6.23. 
coisas que te aconteceram quanto te é lembrá-las. [33.15] Desiste também de provocar risadas, pois tal atitude resvala na vulgaridade, como também pode fazer com que os teus próximos percam o respeito por ti. [33.16] Encetar conversas vergonhosas é perigoso. Quando isso ocorrer, se a ocasião for propícia, repreende quem se comporta assim. $\mathrm{Se}<\mathrm{a}$ ocasião $>$ não $<$ for propícia $>$, mostra, por meio do silêncio, do rubor e de um ar sombrio, que estás descontente com a conversa.

[34] Quando apreenderes a representação de algum prazer - ou de alguma outra coisa - guarda-te e não sejas arrebatado por ela. Que o assunto te espere: concede um tempo para ti mesmo. Lembra então destes dois momentos: um, no qual desfrutarás o prazer; e outro posterior, no qual, tendo-o desfrutado, tu te arrependerás e criticarás a ti mesmo. Compara então com esses dois momentos o quanto, abstendo-te <desse prazer>, tu te alegrarás e elogiarás a ti próprio. Porém, caso a ocasiáo propícia para empreender a ação se apresente, toma cuidado! Que não te vençam sua doçura e sua sedução. Compara isso ao quão melhor será para ti teres a ciência da obtenção da vitória.

[35] Quando discernires que deves fazer alguma coisa, faz. Jamais evites ser visto fazendo-a, mesmo que a maioria suponha algo diferente sobre <a ação>. Pois se náo fores agir corretamente, evita a própria ação. Mas se <fores agir> corretamente, por que temer os que te repreenderâo incorretamente?

[36] Assim como "É dia" e "É noite" possuem pleno valor quando em uma proposição disjuntiva, mas não em uma 
conjuntiva, assim também tomar a maior parte $<$ da comida $>$ tem valor para o corpo, mas não o valor comunitário que é preciso observar em um banquete. Quando então comeres com alguém, lembra de não veres somente o valor para o corpo dos pratos postos à tua frente, mas que também é preciso que guardes o respeito para com o anfitriāo ${ }^{103}$.

[37] Se aceitares um papel além de tua capacidade, tanto perderás a compostura quanto deixarás de lado aquele que é possível que bem desempenhes.

[38] Do mesmo modo que, ao caminhares, tomas cuidado para que não pises em um prego ou não torças o pé, assim também toma cuidado para que não causes dano à tua faculdade diretriz. Se guardarmos atentamente essa regra, nós empreenderemos cada ação com mais segurança.

[39] O corpo é a medida das posses de cada um, como o pé o é da sandália ${ }^{104}$. Se te fixares nisso, guardarás a medida. Mas se fores além, necessariamente cairás no abismo. E assim, igualmente, a respeito da sandália. Se fores muito além do pé ${ }^{105}$, ela torna-se dourada, em seguida púrpura, depois bordada, pois, uma vez ultrapassada a medida, não há mais limite algum.

${ }^{103}$ Boter (1999, p. 134) observa que o sentido geral deste capítulo é o seguinte: 'Assim como A é bom para B, mas mau para C, do mesmo modo tomar a maior parte da comida em um banquete é bom para o teu corpo, mas não para as relaçóes sociais'. A expressáo em grego para 'proposição disjuntiva' é diezeugmenon; para 'proposição conjuntiva' é sympeplegmenon.

${ }^{104}$ Cf. Horácio, Cartas, I.10.12; I.7.98.

${ }^{105}$ Literalmente 'Se tu ultrapassares pé acima'. Aqui se faz referência às sandálias cujas correias se estendem pé acima, sobre as canelas. 
[40] As mulheres, logo após os seus quatorze anos, são chamadas de senhoras pelos homens ${ }^{106}$. Vendo assim que nenhuma outra coisa lhes cabe, exceto se deitarem com eles, começam a se embelezar, e nisso depositam todas as esperanças. É importante então que cuidemos para que percebam que por nenhuma outra coisa são honradas, senão por se apresentarem disciplinadas e dignas ${ }^{107}$.

[41] É sinal de incapacidade ocupar-se com as coisas do corpo, tal como exercitar-se muito, comer muito, beber muito, evacuar muito, copular muito. É preciso fazer essas coisas como algo secundário: que a atenção seja toda para o pensamento.

[42] Quando alguém te tratar mal ou falar mal de ti, lembra que ele o faz ou fala pensando que isso lhe é conveniente. Não lhe é possível, entấo, seguir o que se te afigura, mas o que se lhe afigura, de modo que, se equivocadamente se lhe afigura, aquele que sofre o dano é quem está enganado. Com efeito, se alguém supuser falsa uma proposição conjuntiva verdadeira, não é a proposiçấo conjuntiva que sofre o dano, mas quem se engana. Agindo de acordo com isso, serás gentil com quem te insulta. Diz, pois, em cada uma dessas ocasióes: "Assim lhe parece".

[43] Toda coisa tem dois lados ${ }^{108}$ : um suportável e outro não suportável. < Por exemplo, > se teu irmão for injusto

${ }^{106}$ Hadot (2000, p. 193, nota 1 ) observa que as mulheres romanas de classes altas (tanto as casadas quanto as filhas delas) eram tratadas como domina ('senhora'), Cf. Suetônio, Vida dos doze Césares, Cláudio, 39. De acordo com Justiniano (Inst. I, tit. 22), a idade da puberdade entre os romanos era de 14 anos para os homens e de 12 anos para as mulheres.

107 Aidemones.

108 Cf. Diatribes I.2 (início); III.10.19; Marco Aurélio, VIII.46; Encheiridion 30; Xenofonte, Memoráveis, II.3. 
<contigo >, não o tomes por aí, isto é, que ele é injusto (pois isso não é suportável), mas <toma-o> antes por aqui: que ele é teu irmão, e que fostes criados juntos - assim o tomarás de acordo com o que é suportável ${ }^{109}$.

[44] Estes argumentos são inconsistentes ${ }^{110}$ : "Eu sou mais rico do que tu, logo sou superior a ti"; "Eu sou mais eloquente do que tu, logo sou superior a ti". Mas, antes, estes são consistentes: "Eu sou mais rico do que tu, logo minhas posses são maiores do que as tuas"; "Eu sou mais eloquente do que tu, logo minha eloquência é maior do que a tua”. Pois tu não és nem as posses, nem a eloquência.

[45] Alguém se banha de modo apressado ${ }^{111}$ : não

${ }^{109}$ Neste capítulo, Epicteto faz uma analogia entre uma ânfora e suas duas asas (labas) e cada coisa (pragma) do mundo e os dois modos de abordá-la. Ânforas eram objeto de uso diário na Antiguidade, mas não o são mais, o que dificulta nosso trabalho de traduçáo. Epicteto nos diz que uma das asas é phoreton e a outra aphoreton. Literalmente: uma é sustentável e outra é insustentável (i.e. por uma se pode, por outra náo se pode sustentar a ânfora). Na presente tradução, achamos por bem suprimir a referência a asas e verter a primeira frase simplesmente por 'Toda coisa tem dois lados'. Como a tradução literal dessa frase seria 'Toda coisa <ou negócio> tem duas asas', pensamos em traduzir phoreton e aphoreton por 'adequado' e 'inadequado' e em verter a passagem da seguinte forma: '<Como uma ânfora $>$, toda coisa tem duas asas, uma <adequada>, outra <inadequada para abordá-la>'. Entretanto, tal tradução faria desaparecer algo importante que é expresso no texto grego: dizer que uma das asas é 'insuportável' é dizer que tomar o assunto por aí, além de ser moralmente errôneo, causa dor e sofrimento, pois, para os estoicos, o sofrimento (pathos) ou é efeito de uma falsa opiniáo ou se identifica com uma falsa opinião - i.e. um modo equivocado de lidar com a realidade. A primeira posição é a de Zenão de Cítio, a segunda é a de Crisipo (Cf. Diógenes Laércio, VII, 111), que é seguida também por Epicteto (Cf. Encheiridion 5; Diatribes III.2.3).

110 Cf. Diatribes III.14.11; Sexto Empírico, Esboços de Pirronismo, II.137.

${ }^{111}$ Cf. Diatribes IV.8 (início); III.8.5; III.17.7 ss.; Marco Aurélio, VIII.49. 
digas que ele <se banha $>$ de modo ruim, mas de modo apressado. Alguém bebe muito vinho: não digas que ele $<$ bebe $>$ de modo ruim, mas que <bebe $>$ muito. Pois, antes de discernir a opiniáo dele, como sabes que ele <age> de modo ruim? Assim, não ocorrerá que apreendas as representaçóes compreensivas de umas coisas e dês assentimento a outras ${ }^{112}$.

[46.1] Jamais te declares filósofo ${ }^{113}$. Nem, entre os homens comuns, fales frequentemente sobre princípios filosóficos ${ }^{114}$, mas age de acordo com os princípios filosóficos. Por exemplo: em um banquete, não discorras sobre como se deve comer, mas come como se deve ${ }^{115}$. Lembra que Sócrates, em toda parte, punha de lado as demonstraçóes, de tal modo que os outros o procuravam quando desejavam ser apresentados aos filósofos por ele. E ele os levava! ${ }^{116}$ [46.2] E dessa maneira, sendo desdenhado, ele ia. Com efeito, caso, em meio a homens comuns, uma discussão sobre algum princípio filosófico sobrevenha, silencia ao máximo ${ }^{117}$, pois o perigo de vomitar imediatamente o que não digeriste é grande $^{118}$. E quando alguém te falar que nada sabes e não te morderes, sabe então que começaste a ação. Do mesmo modo que as ovelhas não mostram o quanto comeram, trazendo

${ }^{112}$ Cf. Diatribes III.8.4; Cícero, Acad. I.2; II.12; Luciano, Symposium 23; Marco Aurélio, IV.22; VII.54; Aulo Gélio, XIX.1.

${ }^{113}$ Cf. Diatribes IV.8.17 e 35.

114 Theoremat.

115 Cf. Diatribes I.13; I.14.20; III.21.5; IV.4.8.

116 Cf. Diatribes III.23.22; IV.8.22. White (1983, p. 26, nota 26) observa que talvez Epicteto tenha em mente aqui os eventos da primeira parte do diálogo Protágoras de Platão (310 a- 311 a), onde Sócrates conduz Hipócrates a Protágoras.

${ }^{117}$ Cf. Diatribes I.29.32; III.13.7; III.14.2; IV.4.26; Encheiridion 33.2; Juvenal, De Stoic. II.14.

${ }^{118}$ Cf. Diatribes II.9.17 ss.; III.21.1. 
a forragem ao pastor, mas, tendo digerido internamente o pasto, produzem lã e leite, também tu não mostres os princípios filosóficos aos homens comuns, mas, após tê-los digerido, <mostra $>$ as açóes.

[47] Quanto ao corpo, quando tiveres te adaptado à frugalidade ${ }^{119}$, não te gabes disso. Nem digas, em toda ocasião, se beberes água, que bebes água ${ }^{120}$. E se quiseres, em algum momento, exercitar-te para uma tarefa árdua, faz isso para ti mesmo e não para os outros ${ }^{121}$. Não abraces estátuas ${ }^{122}$, mas se tiveres forte sede, bebe <um gole de > água gelada e cospe $\mathrm{e}^{123}$ - e não digas a ninguém.

[48.a] Postura e caráter do homem comum ${ }^{124}$ : jamais espera benefício ou dano de si mesmo, mas das coisas exteriores. Postura e caráter do filósofo: espera todo benefício e todo dano de si mesmo.

[48.b1] Sinais de quem progride ${ }^{125}$ : não recrimina ninguém, não elogia ninguém, não acusa ninguém, não reclama de ninguém. Nada diz sobre si mesmo - como quem é ou o que sabe. Quando, em relação a algo, é entravado ou impedido, recrimina a si mesmo. Se alguém o elogia, se ri de quem o elogia. Se alguém o recrimina, não se defende.

${ }^{119}$ Cf. Diatribes III.12.

${ }^{120}$ Cf. Diatribes III.14.4.

${ }^{121}$ Cf. Diatribes III.12.17.

${ }^{122}$ Cf. Diatribes III.12.2. De acordo com Diógenes Laércio (6.23), esse era o costume de Diógenes de Sínope, fundador do Cinismo. Apesar dessa crítica a Diógenes, Epicteto o considerava como o modelo de sábio (Cf. Diatribes III.22).

${ }^{123}$ Cf. Diatribes III.12.17. Estobeu (Florilégio, 17, 36) atribui tal exercício a Platão.

${ }^{124}$ Cf. Diatribes III.19; I.21; Encheiridion 29.7.

${ }^{125}$ Cf. Diatribes I.26.15; I.4; II.11; II.17; Encheiridion 5. 
Vive como os convalescentes ${ }^{126}$, precavendo-se de mover algum membro que esteja se restabelecendo, antes que se recupere $^{127}$. [48.b2] Retira de si todo o desejo ${ }^{128}$ e transfere a repulsa unicamente para as coisas que, entre as que são encargos nossos, são contrárias à natureza ${ }^{129}$. Para tudo, faz uso do impulso amenizado ${ }^{130}$. Se parecer insensato ou ignorante, não se importa. Em suma: guarda-se atentamente como $<$ se fosse $>$ um inimigo traiçoeiro.

[49] Quando alguém se crê merecedor de reverência ${ }^{131}$ por ser capaz de compreender e interpretar os livros de Crisipo, diz para ti mesmo: "Se Crisipo não escreveu de modo obscuro, ele não tem pelo que se crer merecedor de reverência" ${ }^{132}$. Mas o que eu desejo? Conhecer a natureza e segui-la. Busco então quem a interpreta. Ouvindo que é Crisipo, vou a ele. Mas não compreendo seus escritos. Busco então quem os interpreta - até aí, absolutamente nada há que mereça reverência. Quando eu acho o intérprete, resta-me

${ }^{126}$ Cf. Diatribes III.13.21.

${ }^{127}$ Cf. Sêneca, Cartas a Lucílio VII (início).

${ }^{128}$ Cf. Encheiridion 2.2; Diatribes I.4.1.

${ }^{129}$ Cf. Encheiridion 2.1.

${ }^{130}$ Aneimene: particípio do verbo aniemi, adjetiva o vocábulo 'impulso'. A expressão é deste modo vertida por outros tradutores: 'He exercises no pronounced choice in regard to anything' (Oldfather, 1928); 'His impulses toward everything are disminished' (White, 1983); 'Il fait usage de l'impulsion avec souplesse' (Gourinat, 1998); 'Usa en todo um impulso no forzado' (García, 1995).

131 No presente capítulo, buscamos unificar o sentido de semnos ('reverenciado, augusto, sagrado') e o verbo relacionado semnyno ('exaltar, afetar um ar grave e solene') para dar conta do jogo de palavras proposto no texto. Assim, traduzimos semnos por 'o que merece reverência' e semnyno por 'crer-se merecedor de reverência'. Cf. Diatribes I.4.6 ss.; II.19.5 ss.; II.23.44.

132 Cf. Diatribes I.17.13. Crisipo (280-207 a.C.) sucedeu Cleanto (discípulo de Zenão de Cítio, fundador do Estoicismo) na direção da escola estoica em Atenas em 232 a.C. 
fazer uso das coisas prescritas - unicamente isso é digno de reverência. Ora, se admiro o próprio < ato de> interpretar, que outra coisa me torno senão gramático ao invés de filósofo? Com a diferença que, no lugar de Homero, interpreto Crisipo. Então, quando alguém me disser "Interpreta algo de Crisipo para mim”, sobretudo enrubescerei quando não for capaz de exibir açóes semelhantes às palavras e condizentes $<$ com elas $>$.

[50] Respeita todas as coisas que foram expostas como se fossem leis, como se cometesses uma impiedade se as transgredisses. E se alguém falar algo de ti, não dês atenção, pois isso não é mais <ação> tua.

[51.1] Por quanto tempo ainda esperarás para que te julgues merecedor das melhores coisas e para que em nada transgridas os ditames da razão? ${ }^{133}$ Recebeste os princípios filosóficos, com os quais foi preciso concordar, e concordaste. Por qual mestre ainda esperas para que confies a ele a correção de ti mesmo? Não és mais um adolescente, já és um homem feito. Se agora fores descuidado e preguiçoso, e sempre fizeres adiamentos após adiamentos, fixando um dia após o outro o dia depois do qual cuidarás de ti mesmo, não perceberás que não progrides. E permanecerás, tanto vivendo quanto morrendo, um homem comum. [51.2] Então, a partir de agora, como um homem feito e que progride, considera a tua vida merecedora de valor. E que seja lei inviolável para ti tudo o que se afigurar como o melhor ${ }^{134}$. Então se uma tarefa árdua, ou prazerosa, ou grandiosa, ou obscura te for apresentada, lembra que essa é a hora da luta, que essa é a hora dos Jogos

${ }^{133}$ Cf. Diatribes II.8 (fim); IV.12.

${ }^{134}$ Cf. Encheiridion 22. 
Olímpicos, e que não há mais nada pelo que esperar, e que, por um revés ou um deslize, perde-se o progresso ou o conserva. [51.3] Deste modo Sócrates realizou-se: de todas as coisas com que se deparou, não cuidou de nenhuma outra, exceto a razão. E tu, mesmo que não sejas Sócrates ${ }^{135}$, deves viver desejando ser como Sócrates.

[52.1] O primeiro e mais necessário tópico da filosofia é o da aplicação dos princípios, por exemplo: "Não sustentar falsidades". O segundo é o das demonstrações, por exemplo: "Por que é preciso não sustentar falsidades?" O terceiro é o que é próprio para confirmar e articular os anteriores, por exemplo: "Por que isso é uma demonstração? $\mathrm{O}$ que é uma demonstração? $\mathrm{O}$ que é uma consequência? O que é uma contradição? O que é o verdadeiro? O que é o falso?" [52.2] Portanto, o terceiro tópico é necessário em razão do segundo, e o segundo, em razão do primeiro - mas o primeiro é o mais necessário e onde é preciso se demorar. Porém, fazemos o contrário: pois no terceiro despendemos nosso tempo, e todo o nosso esforço é em relação a ele, mas do primeiro descuidamos por completo. Eis aí por que, por um lado, sustentamos falsidades e, por outro, temos à mão como se demonstra que não é apropriado sustentar falsidades ${ }^{136}$.

[53.1] É preciso em toda ocasião ter à mão o seguinte:

Conduze-me, Zeus, e tu também, Destino, Para o posto ao qual um dia fui designado,

135 Quanto à referência a Sócrates, cf. Diatribes III.23.21; Platão, Criton, 46 b4- c6.

${ }^{136}$ Cf. Diatribes III.2. 
Que, diligente, eu vos seguirei - e se, mau me tornando,

Não o quiser, ainda assim vos seguirei ${ }^{137}$.

[53.2] Aquele que, de modo justo, ceder à necessidade é, para nós, sábio e conhecedor das coisas divinas ${ }^{138}$.

[53.3] Críton, se assim é desejado pelos Deuses, que assim seja ${ }^{139}$.

[53.4] Ânito e Meleto podem me matar, mas não podem me causar dano ${ }^{140}$.

${ }^{137}$ Esses versos são atribuídos a Cleanto, (331/330-233/232 ou 232/231 a.C.), discípulo direto de Zenão de Cítio (335-264 a.C.), o fundador do Estoicismo. Cf. Diatribes II.16.42; IV.1.131; IV.4.34. Sêneca (Cartas a Lucílio, CVII.10) assim traduz esses célebres versos de Cleanto: Duc, o parens celsique dominator poli,/ quocumque placuit: nulla parendi mora est; / adsum inpiger. Fac nolle, comitabor gemens / malusque patiar facere quod licuit bono./ Ducunt volentem fata, nolentem trahunt. Aldo Dinucci (2007, p. 44) assim traduz tais versos de Sêneca: Conduz-me, ó Pai Excelso e Senhor do mundo,/ Para onde quer que queiras nenhum obstáculo impedir-me-á de seguir-te./ Diligente, estarei junto a ti. E caso eu não queira fazer/ $O$ que é possivel ao intrépido, ainda assim seguir-te-ei, gemendo e infeliz./ $O$ destino conduz quem lhe obedece e arrasta quem lhe opóe resistência.

138 53.2.1-2: verso de tragédia perdida de Eurípides.

${ }^{139}$ Cf. Platão, Críton, 43 d 8-9; Epicteto, Diatribes I.4.24; III.22.95; IV.4.21.

${ }^{140}$ Cf. Platáo, Apologia 30 c-d; Epicteto, Diatribes I.29.18; II.2.25; III.23.21. 


\section{Bibliografia}

\section{EdiçốEs, TRADUÇÕES E COMENTÁRIOS}

AELIANO. Historical Miscellany. Trad. N. G. Wilson. Harvard: Loeb Classical Library, 1997.

AÉLIO ESPARTANO. Historia Augusta, vol. 1. Trad. D. Magie. Harvard: Loeb Classical Library, 1921.

ALEXANDRE DE AFRODÍSIAS. On Fate. Trad. R. W. Sharples. Londres: Duckworth Publishers, 2007.

ANTONIO DE SOUZA. Manual de Epicteto Filósofo. Lisboa: Regia Officina Tipografica, 1785.

ARISTÓFANES. Clouds. Wasps. Peace. Trad. J. Henderson. Harvard: Loeb Classical Library, 1998.

ARISTÓTELES. Athenian Constitution. Eudemian Ethics. Virtues and Vices. Trad. Rackham. Harvard: Loeb, 1935.

ARISTÓTELES. Metaphysics. Trad. Hugh Armstrong Tredennick; G. Cyril. Harvard: Loeb, 1935.

ARISTÓTELES. Nicomachean Ethics. Trad. Rackham. Harvard: Loeb, 1926.

AULO GÉLIO. Attic Nights, vol. I, II, III. Trad. J. C. Rolfe. Harvard: Loeb Classical Library, 1927.

CANINIUS. Simplicii philosophi gravissimi Commentarius in Enchiridion Epicteti. Veneza: Hieronymum Scotum, 1546.

CARTER, E. All the works of Epictetus, wich are now extant, consisting of his Discourses, preserved by Arrian, in four books, the Enchiridion and Fragments. Londres: J. \& F. Rivington, 1758. 
CÍCERO. On Duties (De offciiis). Trad. W. Miller. Harvard: Loeb Classical Library, 1913.

CÍCERO. On Ends (The Finibus). Trad. H. Rackham. Harvard: Loeb Classical Library, 1914.

CÍCERO. On the Nature of the Gods. Academics. Trad. H. Rackham. Harvard: Loeb Classical Library, 1933.

CÍCERO. Tusculan Disputations. Trad. J. E. King. Harvard: Loeb Classical Library, 1927.

CORA LUTZ. Musonius Rufus, the roman Socrates. IN: Yale class. Stud. x, 1947, 3, p. 8-9.

COSMAS DE JERUSALEM. Canons. IN: Patrologia Graeca 98, 459-524.

CRATANDER. Epicteti Encheiridion. Basel: 1531.

DIÓGENES LAÉRCIO. Lives of Eminent Philosophers, vol. I, II. Trad. R. D. Hicks. Harvard: Loeb Classical Library, 1925.

DION CÁSSIO. Roman History. Trad. Cary Foster. Harvard: Loeb Classical Library, 1914-1927.

DU VAIR. Les oeuvres de messire Guillaume Du Vair [...] reveues par l'autheur avant sa mort et augmentées de plusieurs pièces non encore imprimées. Paris: S. Cramoisy, 1625.

EPICTETO. Enchiridion. Trad. G. Long. Nova York: Prometheus, 1991.

EPICTETO. Entretiens. Livre I. Trad. Joseph Souilhé. Paris: Les Belles Lettres, 2002.

EPICTETO. Epictetus Discourses book I. Trad. Dobbin. Oxford: Clarendon, 2008. 
EPICTETO. Epictetus Encheiridion. Trad. G. Boter. Berlim: De Gruyter, 2007.

EPICTETO. Epictetus, The Handbook, the encheiridion. Trad. N. P. White. Cambridge: Hacket, 1983.

EPICTETO. Manual. Trad. P. O. García. Madrid: Editorial Gredos, 1995.

EPICTETO. Manual; Fragmentos. Trad. Paloma Ortiz García. Madrid: Editorial Gredos, 1995.

EPICTETO. Manuel d'Épictète. Trad. P. Hadot. Paris: LGF, 2000.

EPICTETO. Manuale. Trad. E Maltese., Milião: Garzanti, 1990.

EPICTETO. O Encheiridion de Epicteto: edição bilingue. Trad. Aldo Dinucci; Alfredo Julien. São Cristóvão: EdiUFS, 2012.

EPICTETO. O manual de Epicteto. Trad Hans Koranyi. São Paulo: Agência Editora Iris, 1959.

EPICTETO. Pensées (Manuel) in extenso. IN: Les Stoiciens; Textes Choisis. Org. J. Brun. Paris: PUF, 1998, p. 11839.

EPICTETO. Testemunhos e Fragmentos. Trad. Aldo Dinucci; Alfredo Julien. São Cristóvão: EdiUFS, 2008.

EPICTETO. The Discourses of Epictetus as reported by Arrian (Books I, II, III \& IV);Fragments; Encheiridion. Trad. W. A. Oldfather. Cambridge: Loeb, 2000.

EPICTETO. The Discourses of Epictetus, with the Enchiridion and Fragments. Trad. George Long. Londres: George Bell \& Sons, 1877. 
EPICTETO. The Encheiridion of Epictetus and its Three Christian Adaptations. Trad. G. Boter. Leiden: Brill, 1999.

ESTÊVÃO DE BIZÂNCIO. Stephani Byzantii Ethnica. Volumen I: $A-G$. Margarethe Billerbeck et al. (ed.). Berlin/New York: Walter de Gruyter, 2006.

ESTOBEU. Florilegium, vol I e II. Augustus Meineke (ed.). Lipsiae: Taubner, 1855.

EUNÁPIO. Lives of the Philosophers and Sophists. Trad. C. Wilmer. Harvard: Loeb, 1921.

FILOSTRATO. Apollonius of Tyana, Volumea I, II \& III. Trad. P. Christopher. Harvard: Loeb, 2005-6.

FILOSTRATO. Lives of the Sophists. Eunapius: Lives of the Philosophers and Sophists. Trad. C. Wilmer. Harvard: Loeb, 1921.

FÓCIO. Bibliotheca,vol. I;II . Bekker (ed.). Berlin, 1824.

GALENO. Exhortation à l'étude de la médecine. Trad. V. Boudon. Paris: $\quad$ Les Belles Lettres, 2002.

GALENO. Medicine, volumes $i$, ii, iii. Trad. I. Johnston. G. H. R. Horsley. Harvard, Loeb, 2011.

GOURINAT, J. P. Premières leçons sur Le Manuel d'Épictète. Paris: PUF, 1998.

GREGÓRIO NAZIANZENO. Oratio I contra Iulianum, Epistules, ad Philagrium. IN: PATROLOGIA GRAECA 35-37.

HADOT, I. Simplicius. Commentaire sur le Manuel d'Épictète, Introduction et édition critique du texte grec. Leiden: Brill, 1996. 
HALOANDER. Epicteti Encheiridion. Nuremberg: 1529.

HENSE. Musonii Rufi Reliquiae. Leipzig: Teubner, 1905.

HIPÓLITO. Hippolytus Refutationes. Gottingen: Duncker, 1859.

HOMERO. Ilíada, vol. I, II. Trad. A. T. Murray. Harvard: Loeb Classical Library, 1924-5.

HOMERO. Odissey, vol. I, II. Trad. Dimock and A. T. Murray. Harvard: Loeb Classical Library, 1995.

HORÁCIO. Satires. Epistles. The Art of Poetry. Trad. H. R. Fairclough. Harvard: Loeb Classical Library, 1926.

JOÁO CRISÓSTOMO. Homilies. IN: PATROLOGIA GRAECA 60.111.30.

JUSTINIANO. The Institutes. Trad. T. C. Sandars. Londres: Parker and Son, 1853.

JUVENAL. Satires.Trad. Labriole; Villeneuve. Paris: Les Belles Lettres, 1957.

LONGINO. On the Sublime. Trad. W. Fyfe. Harvard: Loeb Classical Library, 1995.

LUCIANO. Phalaris. Hippias or The Bath. Dionysus. Heracles. Amber or The Swans. The Fly. Nigrinus. Demonax. The Hall. My Native Land. Octogenarians. A True Story. Slander. The Consonants at Law. The Carousal (Symposium) or The Lapiths. Trad. M. A. Harmon. Harvard: Loeb Classical Library, 1913.

LUCRÉCIO. On the Nature of Things. Trad. W. H. D. Rouse. Harvard: Loeb Classical Library, 1924.

MACRÓBIO. Saturnalias vol. i, ii, iii. Trad. Kaster, R. A. Harvard: Loeb, 2011. 
MARCIAL. Epigrams. volumes $I, I I, I I I, I V, V$. Trad. D. R. Shackleton Bailey. Harvard: Loeb, 1993.

MARCO AURÉLIO ANTONINO. Marcus Aurelius. Trad. C. R. Haines. Harvard: Loeb Classical Library, 1916.

MÁXIMO PLANUDES. Greek Anthology, vol. I, III. Trad. W. R. Paton. Harvard: Loeb Classical Library, 1916-8.

MEIBOMIUS. Epicteti Manuale et Sententiae. Quibus accedunt Tabula Cebetis, \& alia affinis argumenti, in linguam Latinam conversa a Marco Meibomio. Subjiciuntur ejusdem notae, emendationes Claudii Salmasii in Epictetum, notae illorum \& alius viri docti in dessertationes Epicteti ab Arriano digestas, \& varians scriptura codicum mannu exaratorum. Trajecti Batavorum: Ex officina Gulielmi Broedelet, 1711.

MOULIN, A. Epicteti Encheiridion in Lenguam Gallicam Versum. Lugduni: 1544.

MURACHCO, H. Lingua Grega: visão semântica, lógica, orgânica e funcional. São Paulo: Discurso Editorial/ Editora Vozes, 2001.

NAOGORGUS, T. Moralis Philosophiae Medulla sen Encheiridion Epicteti. Strasburgo: Wendelinum, 1554.

NEOBARIUS. Epicteti Encheiridion. Paris: 1540.

NONNUS. IN: PATROLOGIA GRAECA 36.933.

ORÍGENES. Contra Celsum. IN: Ante-Nicene Fathers, vol. Iv. Trad. Frederick Crombie. Buffalo: Christian Literature Publishing Co., 1885.

ORÍGENES. Contra Celsum. IN: PATROLOGIA GRAECA 11-17, 3.368.

PEROTTO, N. Epicteti enchiridium a Nicolao perotto e graeco 
in latinum translatum. Veneza: 1450.

PLANUDES, M. Greek Anthology, Volume III: Book 9: The Declamatory Epigrams. Trad. W. R. Paton. Harvard: Loeb, 1917.

PLATÃO. Charmides. Alcibiades I and II. Hipparchus. The Lovers. Theages. Minos. Epinomis. Trad.W. R. M. Lamb. Harvard: Loeb, 1927.

PLATÃO. Euthyphro. Apology. Crito. Phaedo. Phaedrus.Trad. H. N. Fowler. Harvard: Loeb Classical Library, 1914.

PLATÃO. First Alcibiades. Trad. W. R. M. Lamb. Harvard: Loeb Classical Library, 1927.

PLATÃO. Laches. Protagoras. Meno. Euthydemus. Trad. W. R. M. Lamb. Harvard: Loeb Classical Library, 1924.

PLATÃO. Republic, vol. I, II. Trad. P. Shorey. Harvard: Loeb Classical Library, 1930-1935.

PlATÃO. Timaeus. Critias. Cleitophon. Menexenus. Epistles. Trad. R. G. Bury. Harvard: Loeb Classical Library, 1929.

PLÍNIO O JOVEM. Letters, vol. I, II. Trad. B. Radice. Harvard: Loeb Classical Library, 1969.

PLUTARCO. Moralia, Volume XIII: Part 2: Stoic Essays. Trad. H. Cherniss. Harvard: Loeb, 1976.

POLIZIANO, A. Epicteti Stoici Enchiridion et Graeco interpretatum ab Angelo Politiano. Veneza: J. Anthonium et Fratres de Sabio, 1479.

PORFÍRIO. De L'abstinence, livre I; Livre II \& III. Trad. J. Bourfartigue; M. Patillon. Paris: Les Belles Lettres, 1977-1979. 
PORFÍRIO. Porphyrii Quaestionum homericarum ad Iliadem pertinentium reliquias collegitdisposuit. Ed. B. G. Teubner. Charleston: Nabu Press, 2010.

PROCÓPIO DE GAZA. Cartas. IN: Epistolographi Graeci. ed. R. Hercher. Paris, 1873, p. 533-598.

PROCÓPIO DE GAZA. Opera Omnia, vol, I, II, III, IV. Trad. Jacobus Havry Jacobus. Leipzig: Teubner, 1964.

RIVAudeAU, A. La Doctrine D'Epictete Stoicien. Paris: Poitiers, 1567.

SCHEGGIUS, J. Epicteti stoici philosophi enchiridion cum Angelo Politiani interpretatione latina - item Arriani commentarius disputationum ejusdem Epicteti. Basiléia: 1554.

SCHENKL, H. Epicteti Dissertationes ab Arriano digestae. Epictetus. Leipzig: Teubner, 1916.

SCHENKL, H. Epictetus Dissertationiones Ab Arriani Digestae. Stutgart, Taubner, 1965.

SCHWEIGHÄUSER, J. Epicteteae Philosophiae Monumenta. 3 volumes. Leipzig: Teubner, 1799.

SCHWEIGHÄUSER. Simplicii Commentarius in Epicteti Enchiridion accedit Enchiridii paraphasis christiana et Nili Enchiridion. 2 vol. Leipsig: Weidmann, 1800.

SÊNECA. Epistles 1-66. Trad. R. M. Gummere. Harvard: Loeb Classical Library, 2001.

SÊNECA. Epistles 66-92. Trad. R. M. Gummere. Harvard: Loeb Classical Library, 2001.

SÊNECA. Moral Essays, vol. II. Trad. J. W. Basore. Harvard: Loeb Classical Library, 2001. 
SÊNECA. Moral Essays, vol. III. Trad. J. W. Basore. Harvard: Loeb Classical Library, 2001.

SEXTO EMPÍRICO. Against the Logicians. Trad. R. G. Bury. Harvard: Loeb Classical Library, 1935.

SEXTO EMPÍRICO. Against the Professors. Trad. R. G. Bury. Harvard: Loeb Classical Library, 1949.

SEXTO EMPÍRICO. Outlines of Pyrrhonism. Trad. R. G. Bury. Harvard: Loeb Classical Library, 1933.

SIMPLÍCIO. Commentaire sur le Manuel d'Épictète, Introduction et édition critique du texte grec. Introdução e edição crítica: Ilsetraut Hadot. Leiden: Brill, 1996.

SIMPLÍCIO. On Epictetus Handbook. 1-26. Trad. C. Brittain; T. Brennan. New York: Cornell, 2002.

SÓFOCLES. Antigone. The Women of Trachis. Philoctetes. Oedipus AT Colonus. Trad. H. Lloyd-Jones. Harvard: Loeb Classical Library, 1994.

SUETÔNIO. Lives of the Caesars, vol I, II. Trad. J. C. Rolfe. Harvard: Loeb Classical Library, 1914.

SUIDAS. Suda. Disponível em: http://www.stoa.org/sol/ TÁCITO, Anais. Trad. Jackson, J. Harvard: Loeb, 1937.

TÁCITO. Agricola. Germania. Dialogue on Oratory. Trad. M. Hutton; W. Peterson. Harvard: Loeb, 1914.

TEMÍSTIO. Orations 6-8. Letters to Themistius, To the Senate and People of Athens, To a Priest. The Caesars. Misopogon. Trad. C. Wilmer. Harvard: Loeb, 1913.

TRINCAVELLI. Arriani Epictetus Graeche. Veneza: 1535.

TUSANUS. Epicteti Encheiridion Graeche. Paris: 1552. 
UPTON, J. Epicteti quae supersunt Dissertationes ab Arriano Collectae. 2 volumes. Londres: 1739-41.

VON ARNIM, H. Stoicorum Veterum Fragmenta vol. 1: Zeno or Zenonis Discipuli. Berlim: De Gruyter, 2005.

VON ARNIM, H. Stoicorum Veterum Fragmenta vol. 2: Chrysippi Fragmenta Logica et Physica. Berlim: De Gruyter, 2005.

VON ARNIM, H. Stoicorum Veterum Fragmenta vol. 3: Chrysippi fragmenta moralia. Fragmenta Successorum Chrysippi. Berlim: De Gruyter, 2005.

WHITE, N. P. Epictetus, The Handbook, the Encheiridion. Cambridge: Hacket, 1983.

WOLF. H. Epicteti Enchiridion: una cum Cebetis Thebani Tabula Grec. \& Lat. Quibus... accesserunt e graeco translata Simplicii in eundem Epicteti libellum doctissima scholia, Arriani commentarium de Epicteti disputationibus libri iiii, item alia ejusdem argumenti in studiosorum gratiam. Basiléia: 1560-3.

XENOFONTE. Cyropaedia, vol. I, II. Symposium. Apology. Trad. Walter Miller. Harvard: Loeb Classical Library, 1914.

XENOFONTE. Memorabilia. Oeconomicus. Symposium. Apology. Trad. E. C. Marchant; O. J. Todd. Harvard: Loeb Classical Library, 1923.

\section{Estudos}

ANNAS, J. Hellenistic Philosophy of Mind. Berkeley: University of California Press, 1991. 
ASMUS. Quaestiones Epicteteae. IN: Friburgi Brisigavorum, J.C.B. Mohr, 1888, p. 31-34.

BAILLY. Dictionnaire Grec-Français. Le Grand Bailly. Paris: Hachette, 2000.

BONHÖEFFER, A. The Ethics of the Stoic Epictetus: An English Translation. Trad. William O. Stephens. Berna: Peter Lang, 2000.

BOSWORTH, A.B. Arrian and the Alani. IN: Harvard Studies in Classical Philology 81, 1977, p. 217-255.

BOTER, G. Epictetus Encheiridion. Leipzig: De Gruyter, 2007.

BOTER, G. The Encheiridion of Epictetus and its Three Christian Adaptations. Leiden: Brill, 1999.

BROOKE, C. Epictetus in Early Modern Europe: 1453-1758. Professor A. A. Long's Epictetus seminar, 14 de Abril de 1999. Berkeley: 1999, p. 1-21.

CHANTRAINE, P. Dictionnaire étymologique de la langue grecque. Paris: Klincksieck, 1984.

CHOTARD, H. Le Périple de la Mer Noire par Arrien. Paris: Durand, 1860.

COLARDEAU. Étude sur Épictète. Paris: Fontemoing, 1903.

DINA PEPPAS-DELMOUSOU. Basis andriantos tou Arrianou. IN: Athens Annals of Archeology, 3, 1970, p. 377-80.

DINUCCI, A. O Manual de Epicteto. Aforismos da Sabedoria Estoica. São Cristóvão, EdiUFS, 2007.

DINUCCI, A. Fragmentos menores de Caio Musônio Rufo; Gaius Musonius Rufus Fragmenta Minora. IN: Trans/ Form/Ação vol.35 n.3 Marília 2012. 
DINUCCI, A. Introdução ao Manual de Epicteto. 3 ed. São Cristóvão: EdiUFS, 2012.

DINUCCI, A.; JULIEN, A. Epicteto: Testemunhos $e$ Fragmentos. São Cristóvão, EdiUFS, 2008.

DUDLEY, D. R. A History of Cynicism. Chicago: Ares, 1980.

FERREIRA, A. B. H. Novo Dicionário Aurélio da Lingua Portuguesa. Rio de Janeiro: Positivo, 2010.

FRANCIS, J. A. Subversive virtue: asceticism and authority in the second-century pagan world. University Park: Pennsylvania State University Press. 1995.

FREDE, M. Stoics and skeptics on clear and distinct impressions IN: Skeptic Tradition. M. Burnyeat (ed.). Berkeley: University of California Press, 1983, p. 65-93.

HADOT, P; HADOT, I. La Parabole de L'escale. IN: Les Stoiciens. Org. Dherbey e Gourinat. Paris: LGF, 2004, p. $437-452$

HARTMANN. Arrian Und Epiktet. IN: Neue Jahrbücher für das klassische altertum, xv, 1905, p. 257; 274-5.

HASSE, W.; TEMPORINI, H. Aufstieg und Niedergang der römischen Welt: Geschichte und Kultur Roms im Spiegel der neueren Forschung, Volume 2. Amsterdam: Walter de Gruyter, 1990.

INWOOD, B; GERSON, L. Pn. Hellenistic Philosophy: Introductory Readings. Indianapolis: Hackett Publishing Co., 1988.

JADAANE, F. L'influence du stoicisme sur la pensée musulmane. Beirute: Dar el-Machreq, 1968.

LAMP, G. W. H. A Patristic lexicon. Oxford: Oxford University Press, 1961. 
LAURENTI. Musonio, maestro di Epitteto. IN: ANRW 2.36.3, 1989, p. 2105-2146.

LESSES, G. Cause and Stoic Impressions. IN: Phronesis vol. XLIII/1, 1998.

Library, 1913.

LIDDELL, H; SCOTT, R; JONES, H. Greek-English Lexicon. Oxford: Clarendon, 1940.

LONG \& SEDLEY. Hellenistic Philosophers, vol. I. Cambridge: Cambridge University Press, 1987a.

LONG \& SEDLEY. Hellenistic Philosophers, vol. II. Cambridge: Cambridge University Press, 1987b.

LONG, A. Notes on Hierocles Stoicus apud Stobaeum. IN: M.S. Funghi (ed.). Le vie della ricerca. Studi in honore di Francesco Adorno. Florença: Olschki, 1996, p. 299-309.

LONG, A. Representation and the self in Stoicism. IN: Companions to Ancient Thought 2: Psychology. Stephen Everson (ed.). Cambridge: Cambridge University Press, 1991, p. 102-120.

MARTHA, C. Les Moralistes sous L'empire romain. Paris: Hachette, 1865.

MILLAR. Epictetus and the Imperial Court. IN: The Journal of Roman Studies, Vol. 55, No. 1/2, Parts 1 and 2, 1965, p. 141-148.

OLDFATHER. Contributions toward a bibliography of Epictetus. Illinois: University of Illinois Press, 1927.

OLIVER PENDLETON, R. Niccolo Perottis Version of The Enchiridion of Epictetus. Urbana: Illinois, 1954. 
OLTRAMARE, A. Les origines de la diatribe romaine. Lausanne: Payot, 1926.

RABELAIS. Gargantua and Pantagruel. Trad. Sir Thomas Urquhart; Peter Anthony Motteux. Ohio: Forgotten Books, 2008.

SHERWIN-WHITE. Pliny's Praetorship again. IN: JRS 47, 1957, p. 126-30.

SORABJI, R. Perceptual Content in the Stoics. IN: Phronesis, vol. XXXV/3, 1990, p. 307-314.

SPALATIN, C. A. Matteo Riccis use of Epictetus. Korea: Waegwan, 1975.

SPANNEUT. Épictète chez les moines IN: MSR 29, 1972, p. $49-57$.

STADTER. Arrian of Nicomedia. Carolina do Norte: Univ of North Carolina Pr, 1980.

STELLWAG. Het Eerste Boek der Diatriben. Amsterdam: H. J. Paris, 1933. 


\section{INDEX LOCORVM}

\section{Aeliano}

Hist. III. 44: 56

Aélio Espartano

Vida de Adriano (IN: Historia Epicteto Augusta) 16.10: 13

\section{Antologia Palatina}

6, 107: 36

9, 372: 36

\section{Aristófanes}

As Nuvens, 363: 48

\section{Aulo Gélio}

Noites Áticas

I.2.6: 19

II.18: 9

XV.11: 9

XVII.19.1-6

XIX.1: 38

\section{Cícero}

Acad.

I.2; II.12: 63

De Finibus

3.7: 21

III, 22: 51

De Natura Deorum

De Officiis

I, 30, 107-33, 121: 46

I, 28 e $31: 45$

Tusc. Disp.

II.22: 45
Dion Cássio

62.26.4: 15

69.8: 15

Diatribes

I.1.7: $41 ; 54$

I.1.18-32: 18

I.1.19

I.1.25

I.1.26-27: 15

I.1.27: 16

I.1.32: 43

I.2: 61

I.2.12-18: 14

I.2.19-21: 15

I.2.19-24: 18

I.4: 64

I.4.1: 38 (bis); 65.

I.4.6 ss.: 65

I.4.2-3: 35; 36

I.4.19: 36

I.4.24: 68

I.6.28:42

I.7.32: 15

I.8.14: 11

I.9.12: 45

I.9.16: 48

I.9.25: 55 


\begin{tabular}{ll} 
I.9.29: $10 ; 16$ & I.26.11: 10 \\
I.9.29-30: 15 & I.26.15: 64 \\
I.9.34: 49 & I.27: 38 \\
I.10: 54 & I.27.6 ss.: 20 \\
I.11.27: 16 & I.27.12: 54. \\
I.12.15 ss.: 42 & I.27.14: 55 \\
I.12.30 ss.: 42 & I.28.23: 49 \\
I.15.8: 15 & I.29.1: 47 \\
I.16.20: 11 & I.29.10: 42 \\
I.17.13: 65 & I.29.18: $47 ; 68$ \\
I.17.21 e $26: 42$ & I.29.28: 56 \\
I.18.11: 42 & I.29.31: 16 \\
I.18.18: 43 & I.29.32: 63 \\
I.18.19: 45 & I.29.37: 16 \\
I.19.19: 10 & I.29.42 ss.: 45 \\
I.19.21: 10 & I.29.64: 45 \\
I.19.21: $10 ; 50$ & I.29.9: 18 \\
I.19.24: 16 & I.29: 58 \\
I.19.6: 16 & II.1.4: 47 \\
I.19.7: 40 & II.1.26-7: 16 \\
I.19.8: 12 & II.1.29 \\
I.20.15: 47 & II.2.20: 56 \\
I.20: 10 & II.2.25: 68 \\
II. $20.9: 47$ & II.5.2: 55 \\
I.21: 64 & II.5.4: 42 \\
I.22.10: $35 ; 42$ & II.6.2: 58 \\
I.22.14: 54 & II.6.8: 35 \\
I.22: 45 & II.6.9: 48 \\
I.24.11: $41 ; 60$ & II.6.22: 16 \\
I.25.8: 16 & II.6.23: 58 \\
I.25.19-20: 16 & II.8.9: 47 \\
I.25.22 & II.8: $47 ; 66$ \\
I.25.28: 40 & II.9.15: 35 \\
& \\
\hline &
\end{tabular}




$\begin{array}{ll}\text { II.9.17 ss.: } 63 & \text { III.3.2: } 54 \\ \text { II.10.6: } 47 ; 48 & \text { III.4: } 57 \\ \text { II.10: } 53 & \text { III.6.5: } 46 \\ \text { II.11: } 40 ; 64 & \text { III.7.6: } 47 \\ \text { II.12.17: } 16 ; 17 ; 58 & \text { III.7: } 12 \\ \text { II.12.17-25: } 17 & \text { III.8.4: } 63 \\ \text { II.13.4: } 58 & \text { III.8.5: } 62 \\ \text { II.14.7: } 42 & \text { III.10.1: } 20 \\ \text { II.14.11 ss.: } 54 & \text { III.10.6: } 47 \\ \text { II.16.14: } 42 & \text { III.10.19: } 61 \\ \text { II.16.22-40: } 40 & \text { III.12: } 64 \\ \text { II.16.30-1: } 16 & \text { III.12.2: } 64 \\ \text { II.16.37: } 44 & \text { III.12.17: } 64 \\ \text { II.16.42: } 68 & \text { III.13.4: } 13 \\ \text { II.17: } 64 & \text { III.13.21: } 38 ; 65 \\ \text { II.17.27: } 40 & \text { III.13.7: } 63 \\ \text { II.18.21 ss.: } 58 & \text { III.14.2: } 63 \\ \text { II.18.24: } 42 ; 58 ; & \text { III.14.4: } 64 \\ \text { II.18.28: } 58 & \text { III.14.7: } 45 \\ \text { II.19.5 ss.: } 65 & \text { III.14.11: } 62 \\ \text { II.19.13: } 35 ; 54 & \text { III.15.14: } 15 \\ \text { II.22: } 64 & \text { III.15: } 15 \\ \text { II.23.33: } 42 & \text { III.15: } 53 \\ \text { II.23.36: } 43 & \text { III.16.4: } 45 \\ \text { II.23.44: } 65 & \text { III.16: } 57 \\ \text { II.24.11: } 41 & \text { III.17.7 ss.: } 62 \\ \text { III.1.2-5: } 48 & \text { III.19: } 40 ; 64 \\ \text { III.1.19: } 48 & \text { III.20: } 46 \\ \text { III.2: } 67 & \text { III.21.1: } 63 \\ \text { III.2.3: } 62 & \text { III.21.5: } 63 \\ \text { III.2.8: } 38 & \text { III.21: } 17 \\ \text { III.2.13: } 38 & \text { III.22.15 e } 19: 54 \\ \text { III.3.15 e } 17: 16 & \text { III.22: } 64 \\ & \end{array}$




\begin{tabular}{|c|c|}
\hline III.22.95: 68 & IV.2.2: 43 \\
\hline III.22.102: 46. & IV.2.9: 45 \\
\hline III.22.105: 42. & IV.4.8: 63 \\
\hline III.23.9: 38 & IV.4.16: 53 \\
\hline III.23.21: 67; 68 & IV.4.18: 38 \\
\hline III.23.21: 67; 68 & IV.4.21: 68 \\
\hline III.23.22: 63 & IV.4.26: 63 \\
\hline III.23: 55; 56; 58 & IV.4.34: 68 \\
\hline III.24.34: 41 & IV.5.7: 44 \\
\hline III. 24.44 ss.: 50 & IV.5.17: 12 \\
\hline III.24.84 ss.: 39 & IV.5.29: 54 \\
\hline III.24.100 e 109: 16 & IV.6.26: 53 \\
\hline III.24.104 ss.: 47 & IV.7.13: 45 \\
\hline III.24.108: 38 & IV.7.20: 42 \\
\hline III.24.113: 54 & IV.8.17 e 35: 63 \\
\hline III.26.28: 54 & IV.8.17-20: 15 \\
\hline III.26-38: 40 & IV.8.22: 63 \\
\hline IV.1.58: 16 & IV.8.23: 48 \\
\hline IV.1.59: 40 & IV.8: 15 \\
\hline IV.1.65 ss.: 35 & IV.8: 62 \\
\hline IV.1.85: 40 & Encheiridion \\
\hline IV.1.109: 42 & $2.1: 65$ \\
\hline IV.1.111: 43 & $2.2: 65$ \\
\hline IV.1.123: 16 & $5: 62 ; 64$ \\
\hline IV.1.131: 68 & 14: 43 \\
\hline IV.10.15: 53 & 14.1: 48 \\
\hline IV.10.19: 43 & $15: 43$ \\
\hline IV.12: 66 & 22: 66 \\
\hline IV.12.16: 53 & 29.7: 64 \\
\hline IV.12.17: 45 & 30: 61 \\
\hline IV.13.7: 42 & 31.13: 50 \\
\hline IV.13.14 ss.: 47. & $33.2: 63$ \\
\hline IV.2: 45 & 36: 44 \\
\hline
\end{tabular}


40: 49

48: 46

48.3: 38

51.2: 48

Fragmento 108 (Schenkl): 57

\section{Diógenes Laércio}

Vida dos flósofos ilustres

VI.23: 64

VII.108: 56

VII.111: 62

VII.160: 45

\section{Estêváo de Bizâncio}

Ethinica 274.17: 15

\section{Estobeu}

Florilégio, 17, 36: 64

Sermo cvi ex telete, de casibus e 68 i: 45

Sermo I e V: 45

\section{Eunápio}

Vida dos Filósofos e dos Sofistas, 454: 15

\section{Filostrato}

Vida dos Sofistas Ilustres 1.7: 15

Vida de Apolônio de Tiana 1.13: 15

\section{Galeno}

De Libris Propriis, 11: 19

Exortação ao estudo das artes médicas, ii: 56

\section{Horácio}

Cartas

I.10.12: 60

I.7.98: 60

\section{Homero}

Iliada, 3, 182: 47
Justiniano

Inst. I, tit. 22: 61

Juvenal

De Stoic. II.14: 63

\section{Longino}

De Sublime, 14: 58

\section{Luciano}

Nigrinus

23: 63

21: 50

Symposium

23: 63

Demonax

55: 20

Marco Aurélio

Meditaçōes

I.7: 13

I.19: 13

III.13: 20

IV.1: 39

IV.3: 20

IV.22: 63

V.20: 39

V.36: 42

VI.50: 39

VII.19: 19

VII.54: 63

VIII.45: 43

VIII.46: 61

VIII.49: 62

VIII.56: 43

IX.7: 38

X.31: 15

XI.37: 38; 39 
XI.37: 38

XI.6: 45

XI.26: 58

XII.36

Macróbio

Saturnálias 1.11.45: 10

Orígenes

Contra Celsum, 6.2: 19

\section{Platáo}

Apologia

28 e: 48

30 c-d: 68

Critias

c6: 68

Criton

43 d 8-9: 68

46 b4- c6: 67

Primeiro Alcibiades

I 129 c7: 22 (bis)

Protágoras

310 a- 311 a: 63

República

X 607 b: 56

\section{Patrologia Graeca}

(36.933) Nonnus: 11

(38.532) Cosmas de Jerusalem: 11

(3.368) João Crisóstomo, Hom.

13 in Acta: 10 (ter)

(60.111.30) Orígenes. Contra Celsum: 11; 19

(35.592.14) Gregório Nazianzeno. Oratio I contra Iulianum; Ep. 32 ad Philagrium 10.2: 11
Plínio o Jovem

Cartas

Obra toda: 58 .

1.10: 15

3.11: 13

22: 12

\section{Porfírio}

Da Abstinência

II, 20-21: 55

Procópio de Gaza

Cartas

XIV: 45

\section{Sêneca}

Cartas a Lucílio

VII (início): 65

XI: 58

XX.9: 14

LXII.3: 14

LXVII.14: 14

LXX: 4

LXXVII: 45

LXXXVIII: 42

XCIV.19: 14

CVII.10: 68

Da Constância do Sábio

5: 37

14: 50

Dos Beneficios

IV, 34: 39

VII.11: 14

VII, 1: 21

Da Tranquilidade da Alma

13: 39 


\section{Sexto Empírico}

Esboços de Pirronismo

II.137: 62

\section{Simplício}

Comentário ao Encheiridion de Epicteto (Commentarius in Epicteti Enchiridion,)

1.05-1.35: 20

1.10-1.40: 21

1.40-1.45: 21

2.05-2.10: 21

2.15 ss.: 21

2.35-2.40: 22

3.1: 22

5.1.5: 2

39.86: 56

44.77.80: 20

45.35: 10

45.36: 11

55.3: 10

65.37: 17

\section{Suidas}

Suda, episilon 2424: 9 (ter); 13;

$17 ; 18$

\section{Suetônio}

Vida dos doze Césares,

Cláudio, 39: 61

Nero. 49.5:10

Domiciano 14.2: 10

Stoicorum Veterum Fragmenta (SVF)

III 563: 48

III 312: 48

\section{Tácito}

Agricola

Anais

11.30; 36: 14

13.11: 14

15: 16

15.49; 60: 14

15.71: 14

34-5: 15

\section{Temístio}

Oraçōes 5, 63 d: 13

\section{Xenofonte}

Memoráveis

I.1.7: 54

I.3.10: 55

I.3.3: 55

IV.3.10: 55

IV.3.16: 55 
(Página deixada propositadamente em branco) 


\section{INDEX RERVM}

Abster-se (apechomai): 52; 58; 59

Açốes convenientes (kathekonta): 53

Afigurar-se (phainomai): 38; 40; 47; 48; 54; 61 (ter); 66

Apreender (uma representação lambano): 59; 63

Arrebatar (synarpazo): 42; 45; 46 (bis); 47; 59

Assentimento (synkatathesis): 63

Ausência de sofrimento (apatheia): 43; 53

Autodomínio (enkrateia): 42

Banquete (symposion; estiasis): 44; 49 (bis); 50 (bis); 57; 60; 63

Consequência (akolouthia): 67

Contradição (mache): 67

Crisipo: 65; 65 n.159; 66 (bis)

Curso sereno [de vida] (euroia biou): 42

Desejo (orexis): 35; 35 n.4; 38 (ter); 38 n. 24; 45; 55 (bis); 65

Desleal (apistos): 50

Desobstruído (akolytos): 36; 36 n.8

Destino (pepromene): 67

Deuses (theoi): 36; 45 (bis); 52; 54 (bis); 55 (bis); 68

Digno (aidemon): 49 (ter); 50 (bis); 61; 66

Diógenes (filósofo cínico): 45
Divinaçáo (mantike): 55

Escolha [a faculdade de] (prohairesis): 39; 39 n.30; 40; 42 (bis); 53

Faculdade diretriz (hegemonikon): 37 n. 19; 53; 60

Felicidade (eudaimonia): 37; 37 n. 18

Filosofia (philosophia): 47; 67

Heráclito de Éfeso: 45

Impulso (horme): 35; 35 n.3; 39; 65; 65, n.157

Indiferente (adiaphoros): 55

Indigno (anaides): 50

Juízo (hypolepsis): 35; 35 n.2; 47; 54

Leal (pistos): 49 (ter); 50

Liberdade (eleutheria): 37; 53

Livre (eleutheros): 36 (bis); 36 n.6; 44; 47

Magnânimo (megalophron): 49

O que está sob nosso encargo (ou 'o que depende de nós' eph'hemin): 35 (bis); 35, n. 1; 36 (ter); 38 (sexiens); 41; 44 (bis); 46 (bis); 47 (bis); 49 (bis); 50; 54 (ter); 55; 65

Opinião (dogma): 40 (ter); 45; 47; 63

Perseverança (karteria): 42; 42 n.45 Posses (ktesis): 36; 49 (bis); 60; 62 (bis) 
Posto (designado pela divindade taxis): 48

Prazer (hedone): 59 (bis)

Princípios filosóficos (ou simplesmente 'princípios' - theoremata): 63 (bis); 63 n.121 64 .

Proposição conjuntiva (sympeplegmenon): 60; 60 n.110; 61

Proposição disjuntiva (diezengmenon): 59; 60 n.110

Refreamento (aphorme): 39; 39 n. 26

Representação (phantasia): 37 (bis); 37 n.19; 41 (bis); 42; 45; 46 (bis); 47; 59; 63

Repulsa (ekklisis): 35; 35 n.5; 38

(bis); 38 (bis); 55 (bis); 65 (bis)

Sábio (sophos): 68

Segundo a natureza (kata physin): 39; 40; 41; 44; 53

Sem entrave (aparadopodistos): 36; 36 n. 8

Sócrates: 40; 48 n.69 e 73; 52; 55; 58; 63; 63 n.123; 67 (ter); 67 n. 142

Tranquilidade (ataraxia): 43; 53

Zeus (Zeus): 67 


\section{TEXTOS GREGOS}

1. Delfim F. Leão e Maria do Céu Fialho: Plutarco. Vidas Paralelas - Teseu e Rómulo. Tradução do grego, introdução e notas (Coimbra, CECH, 2008).

2. Delfim F. Leão: Plutarco. Obras Morais - O banquete dos Sete Sábios. Tradução do grego, introdução e notas (Coimbra, $\mathrm{CECH}, 2008)$.

3. Ana Elias Pinheiro: Xenofonte. Banquete, Apologia de Sócrates. Tradução do grego, introdução e notas (Coimbra, $\mathrm{CECH}, 2008)$.

4. Carlos de Jesus, José Luís Brandão, Martinho Soares, Rodolfo Lopes: Plutarco. Obras Morais - No Banquete $I$ - Livros I-IV. Tradução do grego, introdução e notas. Coordenação de José Ribeiro Ferreira (Coimbra, CECH, 2008).

5. Ália Rodrigues, Ana Elias Pinheiro, Ândrea Seiça, Carlos de Jesus, José Ribeiro Ferreira: Plutarco. Obras Morais - No Banquete II - Livros V-IX. Tradução do grego, introdução e notas. Coordenação de José Ribeiro Ferreira (Coimbra, $\mathrm{CECH}, 2008$ ).

6. Joaquim Pinheiro: Plutarco. Obras Morais - Da Educação das Crianças. Tradução do grego, introdução e notas (Coimbra, CECH, 2008).

7. Ana Elias Pinheiro: Xenofonte. Memoráveis. Tradução do grego, introdução e notas (Coimbra, CECH, 2009).

8. Carlos de Jesus: Plutarco. Obras Morais - Diálogo sobre o Amor, Relatos de Amor. Tradução do grego, introdução e notas (Coimbra, CECH, 2009). 
9. Ana Maria Guedes Ferreira e Ália Rosa Conceição Rodrigues: Plutarco. Vidas Paralelas - Péricles e Fábio Máximo. Tradução do grego, introdução e notas (Coimbra, $\mathrm{CECH}, 2010)$.

10. Paula Barata Dias: Plutarco. Obras Morais - Como Distinguir um Adulador de um Amigo, Como Retirar Beneficio dos Inimigos, Acerca do Número Excessivo de Amigos. Tradução do grego, introduçâo e notas (Coimbra, $\mathrm{CECH}, 2010)$.

11. Bernardo Mota: Plutarco. Obras Morais - Sobre a Face Visivel no Orbe da Lua. Tradução do grego, introdução e notas (Coimbra, CECH, 2010).

12. J. A. Segurado e Campos: Licurgo. Oração Contra Leócrates. Tradução do grego, introdução e notas (Coimbra, $\mathrm{CECH}$ /CEC, 2010).

13. Carmen Soares e Roosevelt Rocha: Plutarco. Obras Morais - Sobre o Afecto aos Filhos, Sobre a Música. Tradução do grego, introdução e notas (Coimbra, $\mathrm{CECH}, 2010)$.

14. José Luís Lopes Brandão: Plutarco. Vidas de Galba e Otão. Tradução do grego, introdução e notas (Coimbra, $\mathrm{CECH}, 2010)$.

15. Marta Várzeas: Plutarco. Vidas de Demóstenes e Cícero. Tradução do grego, introdução e notas (Coimbra, $\mathrm{CECH}, 2010)$.

16. Maria do Céu Fialho e Nuno Simóes Rodrigues: Plutarco. Vidas de Alcibiades e Coriolano. Traduçấo do grego, introdução e notas (Coimbra, CECH, 2010).

17. Glória Onelley e Ana Lúcia Curado: Apolodoro. Contra Neera. [Demóstenes] 59. Tradução do grego, introdução e notas (Coimbra, CECH, 2011). 
18. Rodolfo Lopes: Platão. Timeu-Critías. Tradução do grego, introdução e notas (Coimbra, CECH, 2011).

19. Pedro Ribeiro Martins: Pseudo-Xenofonte. A Constituição dos Atenienses. Tradução do grego, introdução, notas e índices (Coimbra, CECH, 2011).

20. Delfim F. Leão e José Luís L. Brandão: Plutarco.Vidas de Sólon e Publicola. Tradução do grego, introdução, notas e índices (Coimbra, CECH, 2012).

21. Custódio Magueijo: Luciano de Samósata I. Tradução do grego, introdução e notas (Coimbra, CECH/IUC, 2012).

22. Custódio Magueijo: Luciano de Samósata II. Tradução do grego, introduçẫo e notas (Coimbra, CECH/IUC, 2012).

23. Custódio Magueijo: Luciano de Samósata III. Tradução do grego, introdução e notas (Coimbra, CECH/IUC, 2012).

24. Custódio Magueijo: Luciano de Samósata IV. Tradução do grego, introdução e notas (Coimbra, CECH/IUC, 2013).

25. Custódio Magueijo: Luciano de Samósata V. Tradução do grego, introdução e notas (Coimbra, CECH/IUC, 2013).

26. Custódio Magueijo: Luciano de Samósata VI. Tradução do grego, introdução e notas (Coimbra, CECH/IUC, 2013).

27. Custódio Magueijo: Luciano de Samósata VII. Tradução do grego, introdução e notas (Coimbra, CECH/IUC, 2013).

28. Custódio Magueijo: Luciano de Samósata VIII. Tradução do grego, introdução e notas (Coimbra, CECH/IUC, 2013).

29. Custódio Magueijo: Luciano de Samósata IX. Traduçâo do grego, introdução e notas (Coimbra, CECH/IUC, 2013). 
30. Reina Marisol Troca Pereira: Hiérocles e Filágrio. Philogelos (O Gracejador). Tradução do grego, introdução e notas (Coimbra, CECH/IUC, 2013).

31. J. A. Segurado e Campos: Iseu. Discursos. VI. A herança de Filoctémon. Tradução do grego, introdução e notas (Coimbra, CECH/IUC, 2013).

32. Nelson Henrique da Silva Ferreira: Aesopica: a fábula esópica e a tradição fabular grega. Estudo, traduçáo do grego e notas. (Coimbra, CECH/IUC, 2013).

33. Carlos A. Martins de Jesus: Baquílides. Odes e Fragmentos Tradução do grego, introdução e notas (Coimbra e Sáo Paulo, IUC e Annablume, 2014).

34. Alessandra Jonas Neves de Oliveira: Eurípides. Helena. Tradução do grego, introdução e notas (Coimbra e São Paulo, IUC e Annablume, 2014).

35. Maria de Fátima Silva: Aristófanes. Rãs. Tradução do grego, introdução e notas (Coimbra e São Paulo, IUC e Annablume, 2014).

36. Nuno Simões Rodrigues: Eurípides. Ifigénia entre os tauros. Tradução do grego, introdução e notas (Coimbra e São Paulo, IUC e Annablume, 2014).

37. Aldo Dinucci \& Alfredo Julien: Epicteto. Encheiridion. Tradução do grego, introdução e notas (Coimbra e São Paulo, IUC e Annablume, 2014). 
IMPRESSÃO:

Artipol - Artes tipográficas, Lda.

Zona industrial de Mourisca do Vouga, Apartado 3051 3754-901 ÁguedA 
(Página deixada propositadamente em branco) 
Epicteto, um dos grandes nomes do Estoicismo Imperial, nasceu no ano 55, em Hierápolis, na Frígia, e morreu por volta de 135, em Nicópolis. Entre 89 e 94, quando Domiciano expulsou de Roma todos os filósofos, Epicteto se retirou para Nicópolis, onde abriu sua escola de filosofia, que logo se tornou renomada. Seu pensamento nos chegou através de seu aluno Lúcio Flávio Arriano Xenofonte, cidadão romano de origem grega, que compilou suas aulas em oito livros, dos quais quatro sobrevivem, e constituiu o Encheiridion de Epicteto, tomando por base suas anotaçóes das aulas do mestre. Consistindo em um conjunto de apotegmas para que o seguidor do Estoicismo tenha sempre ao alcance da mão os princípios para enfrentar as dificuldades da vida e vencê-las, o Encheirídion tornou célebre o nome de Epicteto, merecendo um amplo comentário de Simplício, que nos chegou. 


\section{OBRA PUBLICADA \\ COM A COORDENAÇÁO \\ CIENTÍFICA}

0
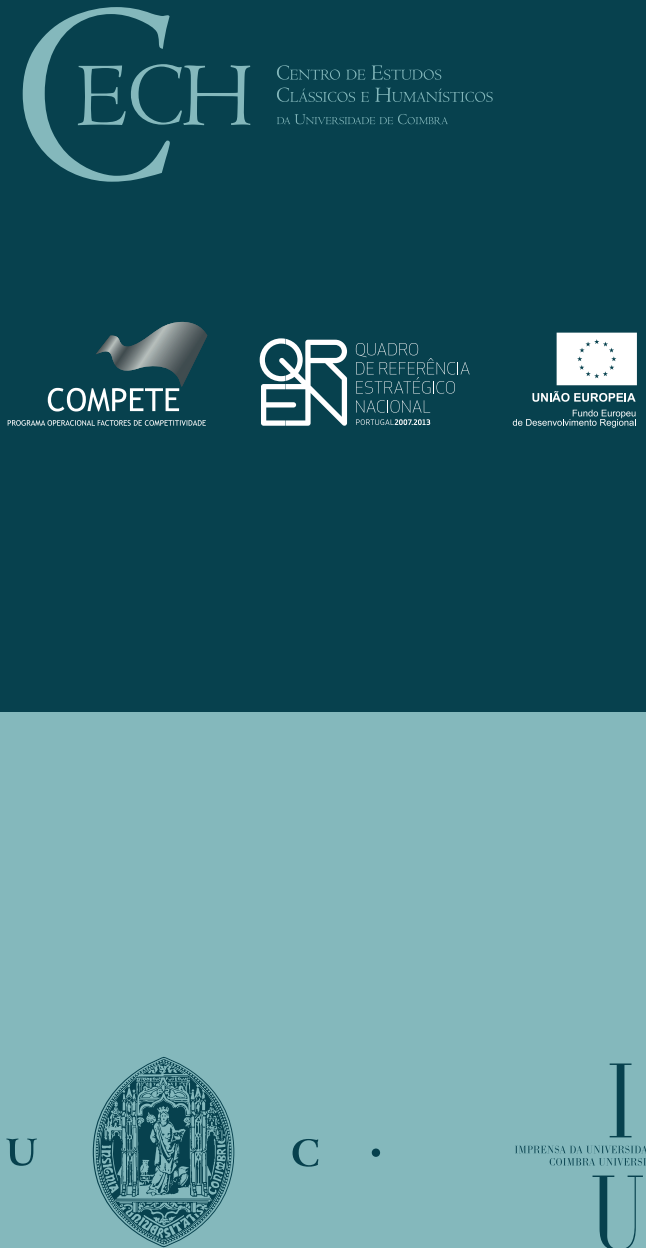

C •

MPRENSA DA IVIIERSIDADE DE COIVBPA 